\title{
Stratigraphy and Age of a Prominent Paleosol in a Late Pleistocene Sedimentary Sequence, Mason Neck, Virginia
}

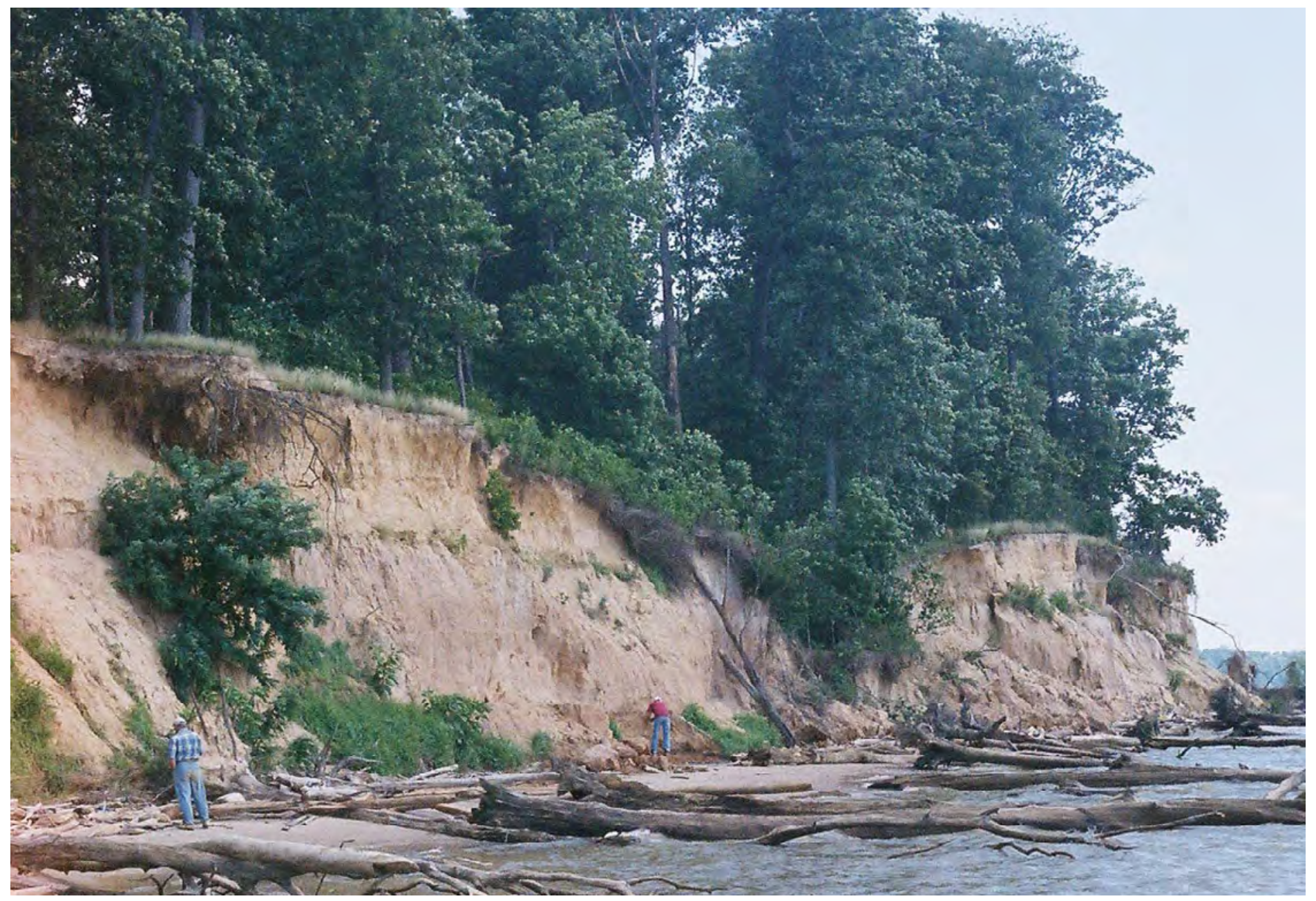

Open-File Report 2021-1113 
Cover. Shoreline cliff face near High Point, Mason Neck, Fairfax County, Virginia. Coauthors Douglas A. Wysocki and Milan J. Pavich are in the photograph. Photograph taken by Helaine W. Markewich, U.S. Geological Survey. 


\section{Stratigraphy and Age of a Prominent Paleosol in a Late Pleistocene Sedimentary Sequence, Mason Neck, Virginia}

By Helaine W. Markewich, Douglas A. Wysocki, Milan J. Pavich, Joseph P. Smoot, and Ronald J. Litwin

Open-File 2021-1113 


\section{U.S. Geological Survey, Reston, Virginia: 2021}

For more information on the USGS — the Federal source for science about the Earth, its natural and living resources, natural hazards, and the environment-visit https://www.usgs.gov or call 1-888-ASK-USGS.

For an overview of USGS information products, including maps, imagery, and publications, visit https://store.usgs.gov.

Any use of trade, firm, or product names is for descriptive purposes only and does not imply endorsement by the U.S. Government.

Although this information product, for the most part, is in the public domain, it also may contain copyrighted materials as noted in the text. Permission to reproduce copyrighted items must be secured from the copyright owner.

Suggested citation:

Markewich, H.W., Wysocki, D.A., Pavich, M.J., Smoot, J.P., and Litwin, R.J., 2021, Stratigraphy and age of a prominent paleosol in a late Pleistocene sedimentary sequence, Mason Neck, Virginia: U.S. Geological Survey Open-File Report 2021-1113, 24 p., https://doi.org/10.3133/ofr20211113.

ISSN 2331-1258 (online) 


\section{Acknowledgments}

Funding for the field work and for collection and analyses of laboratory samples was provided by the U.S. Geological Survey (USGS) National Cooperative Geologic Mapping Program and the USGS Climate and Land-Use Change Research and Development Program. We thank the personnel of Mason Neck State Park, Virginia Department of Conservation and Recreation; Elizabeth Hartwell Mason Neck Wildlife Preserve, U.S. Fish and Wildlife Service; and Potomac Shoreline Regional Park, U.S. National Park Service for access to the study sites. We also thank Daniel R. Muhs, USGS, and Marci M. Robinson, USGS, for reviewing the manuscript. 



\section{Contents}

Acknowledgments ……...................................................................................................................

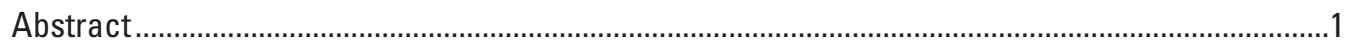

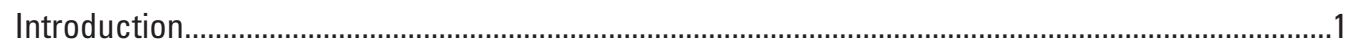

Stratigraphy and Age of Units in Mason Neck Cliff Face Exposures.................................................

Pedostratigraphy and Age of the High Point Paleosol .................................................................

High Point Paleosol Site Description..................................................................................11

High Point Paleosol Profile Description ...............................................................................15

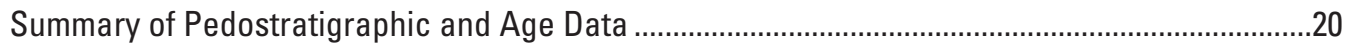

General Observation Based on Data Presented in this Report........................................................21

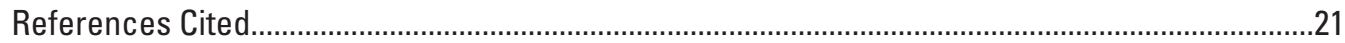

\section{Figures}

1. Maps showing locations of States, water bodies, and glacial boundaries in the Chesapeake Bay and Delaware Bay areas of the eastern United States ........................2

2. Map of the Mason Neck peninsula showing the approximate boundaries of Mason Neck State Park, Mason Neck National Wildlife Refuge, Pohick Bay Regional Park, Gunston Hall Plantation, Fort Belvoir Military Base, locations of the three shoreline cliff faces referred to in this report (High Point, Visitor Center, and Sycamore Point) and an outcrop of surficial gravel mentioned in the report..

3. Photograph of the shoreline cliff face at the High Point locality showing optically stimulated luminescence ages of Units $B$ and $D$ and the stratigraphic position of the High Point paleosol in Unit C.

4. Generalized stratigraphy and optically stimulated luminescence ages for the sedimentary sequence exposed in the shoreline cliff face at the High Point locality......6

5. Generalized stratigraphy and optically stimulated luminescence ages for the sedimentary sequence exposed in the shoreline cliff face at the Visitor Center locality

6. Generalized stratigraphy and optically stimulated luminescence ages for the sedimentary sequence exposed in the shoreline cliff face at the Sycamore Point locality.

7. Photographs and pedostratigraphy (parts $A 1, A 2$, and $B$ ) and lithostratigraphy (part $C)$ of the High Point paleosol, described and sampled from the High Point shoreline cliff-face locality, Mason Neck, Virginia.

\section{Tables}

1. Optically stimulated luminescence (OSL) ages for late Pleistocene quartz-rich sand samples exposed in shoreline cliff faces of Mason Neck, Virginia

2. Particle size distribution in weight percent for the High Point paleosol exposed in the High Point shoreline cliff face, Mason Neck, Virginia.

3. Particle size ratios for the High Point paleosol exposed in the High Point shoreline cliff face, Mason Neck, Virginia. 
4. Bulk density and water content data for the High Point paleosol exposed in the High Point shoreline cliff face, Mason Neck, Virginia.

5. Major-element data ratios for the High Point paleosol exposed in the High Point shoreline cliff face, Mason Neck, Virginia .....

6. Clay mineralogy X-ray diffraction data for the High Point paleosol exposed in the High Point shoreline cliff face, Mason Neck, Virginia..

7. Selected trace-element data for the High Point paleosol exposed in the High Point shoreline cliff face, Mason Neck, Virginia

\section{Conversion Factors}

U.S. customary units to International System of Units

\begin{tabular}{|c|c|c|}
\hline Multiply & By & To obtain \\
\hline \multicolumn{3}{|c|}{ Length } \\
\hline inch (in.) & 2.54 & centimeter $(\mathrm{cm})$ \\
\hline inch (in.) & 25.4 & millimeter (mm) \\
\hline foot $(\mathrm{ft})$ & 0.3048 & meter (m) \\
\hline
\end{tabular}

International System of Units to U.S. customary units

\begin{tabular}{lll}
\hline \multicolumn{1}{c}{ Multiply } & By & To obtain \\
\hline & Length & \\
centimeter $(\mathrm{cm})$ & 0.3937 & inch (in.) \\
millimeter $(\mathrm{mm})$ & 0.03937 & inch (in.) \\
meter $(\mathrm{m})$ & 3.281 & foot (ft) \\
kilometer $(\mathrm{km})$ & 0.6214 & mile (mi) \\
\hline
\end{tabular}




\section{Abbreviations}

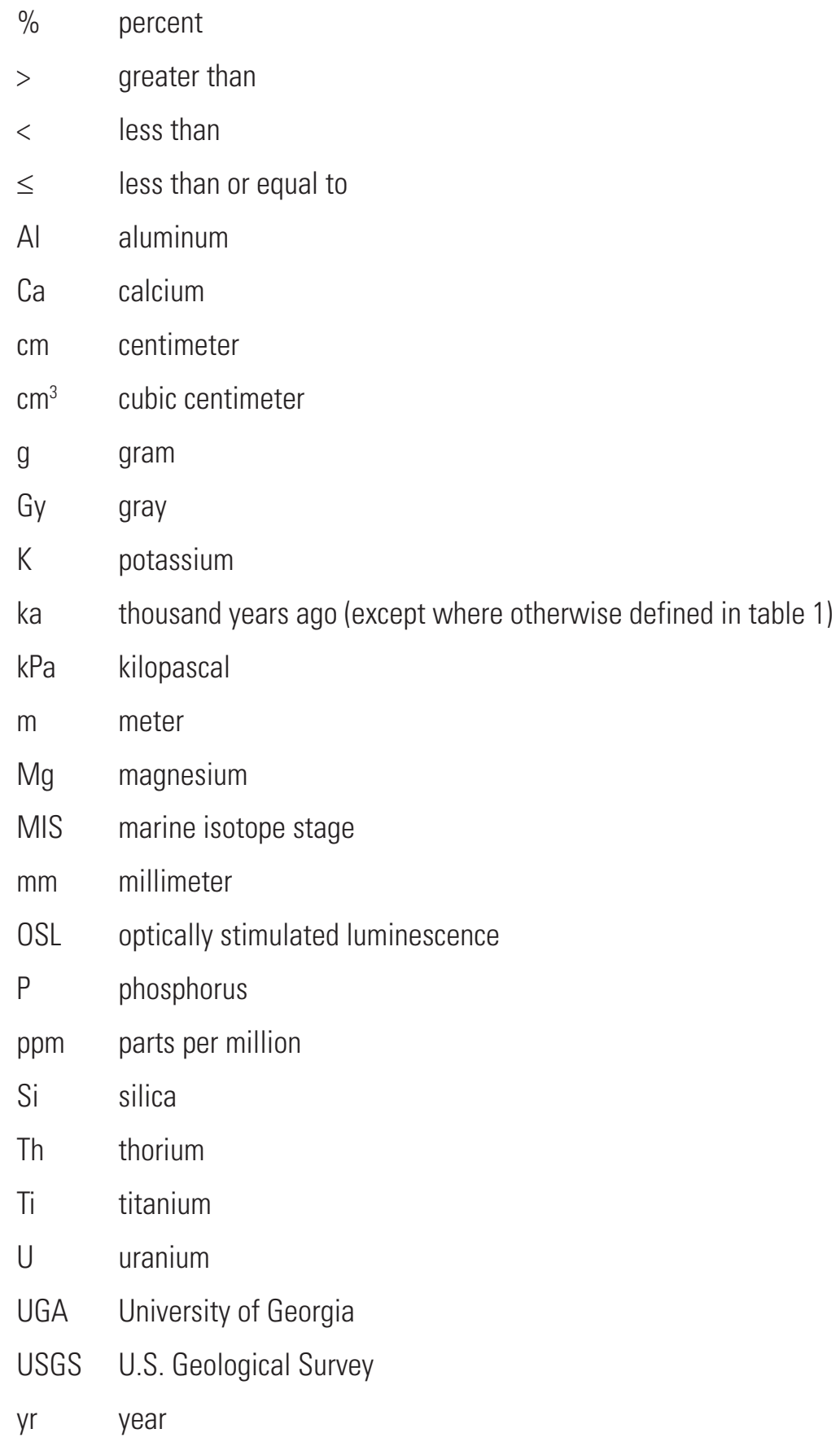





\title{
Stratigraphy and Age of a Prominent Paleosol in a Late Pleistocene Sedimentary Sequence, Mason Neck, Virginia
}

\author{
By Helaine W. Markewich, ${ }^{1}$ Douglas A. Wysocki, ${ }^{2}$ Milan J. Pavich, ${ }^{3}$ Joseph P. Smoot, ${ }^{3}$ and Ronald J. Litwin ${ }^{3}$
}

\section{Abstract}

The High Point paleosol is 2.28-meters-thick aggradational soil developed in fining upward estuarine-alluvial sand and loess. The paleosol is exposed in a few shoreline cliff faces of Mason Neck, Virginia. Although a former A horizon is missing, the $\mathrm{E}, \mathrm{Bw}, \mathrm{Bt}$, and $\mathrm{C}$ horizon sequence seen in the sediments indicates subaerial pedogenesis. Pedogenesis began with initial estuarine-alluvial floodplain emergence as sea level was lowering in late marine isotope stage 5 (MIS5) and MIS4, continued during eolian silt deposition accompanied by incorporation of the silt into the estuarine-alluvial sand, and ended with a period of loess and eolian sand deposition, erosion, and development of periglacial(?) features. Six optically stimulated luminescence ages provide an age range from 86 to $56 \mathrm{ka}$ (thousand years ago) for sedimentary units below and above the paleosol. These ages indicate a 10,000- to 30,000-year interval in late MIS5 and MIS4 for these events to have occurred.

\section{Introduction}

Tidal river estuaries are present at the mouths of most rivers along the eastern shore of the United States from southeastern New York to northeastern Florida. Many of these estuaries are large and have shoreline lengths greater than 10,000 kilometers $(\mathrm{km})$ (for example, Berman, 2010; Eulie and others, 2017). The rivers that flow into these estuaries flow through primarily clastic sediments of the Atlantic Coastal Plain physiographic province, which lies seaward of the Atlantic Fall Zone (fig. 1A). Three of the largest estuaries are Delaware Bay (New Jersey and Delaware; fig. $1 B-C$ ); Chesapeake Bay (Delaware, Maryland, and Virginia; fig. $1 B-C$ ) and Albemarle Sound-Pamlico Sound (North Carolina; northern part of Pamlico Sound shown in fig. 1B). In this report, the term "northern Chesapeake Bay area" includes Delaware Bay and Chesapeake Bay north of the Potomac River.

\footnotetext{
${ }^{1}$ U.S. Geological Survey.

${ }^{2}$ National Resource Conservation Service, retired.
}

${ }^{3}$ U.S. Geological Survey, retired.
The northern Chesapeake Bay area is less than $150 \mathrm{~km}$ beyond the middle- and late-Pleistocene maximum continental glacial limits in the northeastern United States (fig. 1B). Nearsurface sediments in the northern Chesapeake Bay area reflect climatic variations associated with these continental-scale glacial and interglacial episodes. Many of the near-surface sediments are late Pleistocene age $(<130$ thousand years ago [ka]). These late Pleistocene sediments include estuarine, estuarine-alluvial, and alluvial deposits of sand, silty sand, and clay that range in age from about 130 to $30 \mathrm{ka}$ and eolian sand and silt that range in age from about 70 to $5 \mathrm{ka}$. Temporal and spatial (age and elevation) relations of the shoreline deposits throughout the Chesapeake Bay region differ from modeled global sea-level highstands (Potter and Lambeck, 2004; Wehmiller and others, 2004; Pavich and others, 2009; Scott and others, 2010; DeJong and others, 2015). Researchers have explained these discrepancies in elevation and age as being the result of glacial isostatic adjustment processes (crustal deformation) resulting from decay of the last middle-Pleistocene continental glaciation (marine isotope stage, MIS6) and subsequent growth of the late Pleistocene glacial forebulge (late MIS3 and MIS2). There is no agreement with regard to the degree of deformation or whether or not the deformation is uniform. Although these issues continue to be debated, there is general agreement that late Pleistocene shoreline deposits within several meters $(\mathrm{m})$ of present sea level reflect warm climatic conditions and deposition during global sea-level highstands. For discussion of the temporal and spatial relations of shoreline deposits throughout the region, the reader is referred to Potter and Lambeck (2004), Wehmiller and others (2004), Pavich and others (2009), Litwin and others (2010, 2013), Scott and others (2010), DeJong and others (2015); and references in each of those publications.

Eolian and water-lain eolian (alluvial-eolian and estuarine-eolian) deposits in the northern Chesapeake Bay area overlie many of the late Pleistocene estuarine, estuarinealluvial, and alluvial deposits. These deposits of eolian origin serve as evidence for the intermittent periods ( 1,000 to 10,000 years) of much cooler-than-present temperatures, cold temperate coniferous forest vegetation, and landscape-modifying winds that characterized the late Pleistocene northern Chesapeake Bay area climate in late MIS5 through early MIS3 (Newell and Clark, 2008; Markewich and others, 2009, 2015; Litwin and others, 2010, 2013; Wah and others, 2018; and 

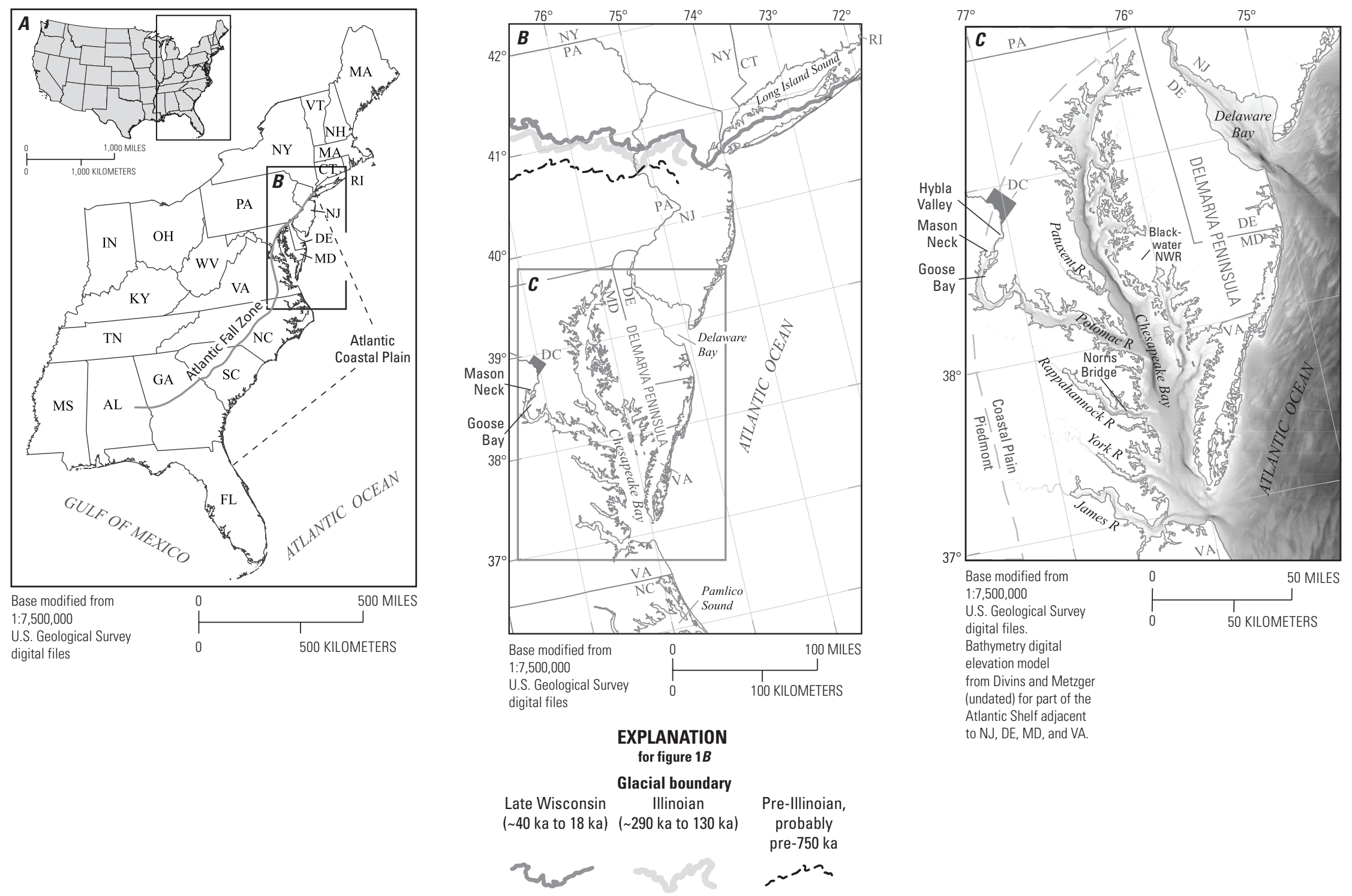

Figure 1. Maps showing locations of States, water bodies, and glacial boundaries in the Chesapeake Bay and Delaware Bay areas of the eastern United States. $A$, Map of the contiguous United States with a part of the coastal area of the northeastern United States outlined in the inset that represents the area in part $B$. $B$, Coastal areas of Connecticut (CT), New York (NY), Pennsylvania (PA), New Jersey (NJ), Delaware (DE), Maryland (MD), Virginia (VA), North Carolina (NC); the Delmarva Peninsula; and Washington, D.C. (DC); and the approximate boundaries for three advances of the Laurentide Ice Sheet. C, Chesapeake Bay area. Figure 1 is modified from figure 1 in Markewich and others (2009). Glacial ages after Stanford and others (2021). Abbreviations: ka, thousand years ago; NWR, National Wildlife Refuge; R, River. 
references in each of those publications). A paleovegetation study of core sediments by Litwin and others $(2010,2013)$ showed that in MIS4 ( 70-56 ka) the northern Chesapeake Bay area as far south as the Potomac River valley (Hybla Valley in fig. 1C) had submillennial-to-millennial-scale shifts in regional temperatures "that closely tracked the Greenland paleoclimatic sequence."

Landform studies also have documented evidence for late Pleistocene intermittent cold climate intervals in the northern Chesapeake Bay area. Periglacial geomorphic processes, such as permafrost aggradation and degradation, produce specific landforms. These landforms include thermokarst structures and frost fissures that have been observed in near-surface sediments from New Jersey to the Blackwater National Wildlife Refuge on the Delmarva Peninsula (French and others, 2007, 2009; Lowery and others, 2010; Newell and DeJong, 2011; Markewich and others, 2015; fig. $1 C$ in this report). Structures indicating periglacial processes (desiccation cracks/frost fissures and bowl-shaped pods/thermokarst features) are present in sediments exposed in shoreline cliff faces of the Mason Neck, a peninsula that juts out into the Potomac River tidal estuary just downstream from Washington, D.C. (figs. 1C, 2). This report presents age, stratigraphic, and paleopedologic data for the four-unit sedimentary sequence, including a prominent paleosol, that is exposed in shoreline cliff faces of Mason Neck. The paleosol is best expressed in the High Point stratigraphic section (figs. 3, 4), and the paleosol description in this report is for that section. The marine-isotope-stage age assignments are based on the LR04 stack in Railsback and others (2015, fig. 3).

\section{Stratigraphy and Age of Units in Mason Neck Cliff Face Exposures}

The Mason Neck peninsula is approximately $40 \mathrm{~km}$ southwest of Washington, D.C. (DC in figs. $1 B-C, 2$ ) and for the most part is under Federal, State, or county jurisdiction (fig. 2). Cliff faces along the shoreline of the Mason Neck peninsula expose a stacked sequence of Pleistocene sediments that has been mapped as the middle Pleistocene Shirley Formation (Mixon and others, 1989; Davis and others, 2001) and as both the middle Pleistocene Shirley Formation and the upper Pleistocene Sedgefield Member of the Tab Formation
(Lyttle and others, 2017). Mixon and others (1989) described the Shirley Formation as "... surficial deposits of riverine terraces and relict bay mouth barriers and bay-floor plains..." and noted that these terraces, barriers, and plains occur at elevations between 10.7 to $13.7 \mathrm{~m}$. Mixon and others (1989) considered the Shirley Formation to be late-middle Pleistocene, basing this assignment on an $184 \pm 20 \mathrm{ka}$ age for an Astrangia coral from estuarine to near-shore marine deposits that are present near Norris Bridge (fig. 1C) in the lower Rappahannock River area of southeastern Virginia (Mixon and others, 1982). By 1992, this U-series coral age for fossiliferous strata in the lower Rappahannock valley was considered inaccurate (footnote 3 in Wehmiller and others, 2004). Mixon and others (1982) reported U-series coral ages of $79 \pm 5 \mathrm{ka}$ and $62 \pm 2 \mathrm{ka}$ for the Norfolk Formation in southeastern Virginia and units of similar age on the Delmarva Peninsula (fig. $1 B-C$ ) of Virginia and Maryland. These ages generally agreed with those of Oaks and Coch (1973) who had reported a U-series age range of 86 to $62 \mathrm{ka}$ for corals from the Norfolk Formation in southeastern Virginia.

The sedimentary sequence of estuarine-alluvial, waterlain eolian, eolian, and alluvial sediments exposed in three Mason Neck shoreline cliff faces has four identifiable/mappable units (from oldest to youngest, Units A-D; figs. 3-6). This sedimentary sequence is well exposed at the High Point, Visitor Center, and Sycamore Point localities (locations in fig. 2). The character of the sequence varies among the localities but the sequence at each locality defines the same package of sediments (figs. 4-6). A prominent paleosol is developed in Unit C, which is a 1- to 3-m-thick deposit of sandy silt, silt, and sand that is in part eolian. Optically stimulated luminescence (OSL) ages for the sediments exposed at the three localities range from 86 to $56 \mathrm{ka}$ and limit the period of sediment deposition and paleosol formation to late-middle and late MIS 5a, MIS4, and early MIS3 (Pavich and others, 2010; Wysocki and others, 2010; figs 3-6 and table 1 in this report). This age range agrees with OSL ages for near-present sea level ( $<+5 \mathrm{~m}$ elevation) estuarine sand and silt at localities in the Potomac River valley near Mason Neck. These localities are (1) $70 \pm 9 \mathrm{ka}$ (MIS5a-MIS4), shoreline cliff face at Goose Bay, Maryland (Markewich and others, 2009; fig. $1 B-C$, in this report); and (2) 84 \pm 9 ka (MIS5a), Hybla 3 core in Hybla Valley, Virginia (Litwin and others, 2013; fig. $1 C$ in this report). 


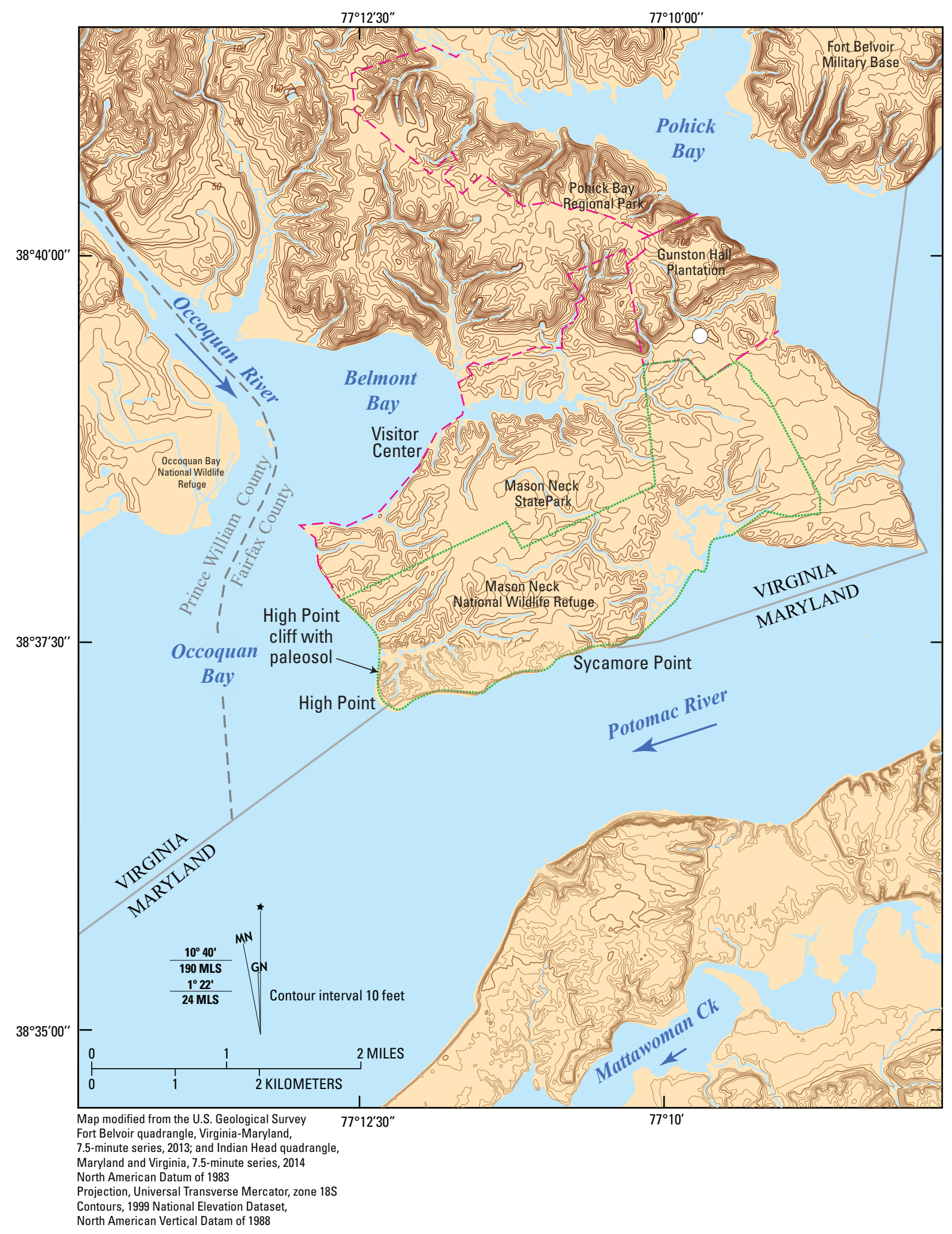

Figure 2. Map of the Mason Neck peninsula showing the approximate boundaries of Mason Neck State Park, Mason Neck National Wildlife Refuge, Pohick Bay Regional Park, Gunston Hall Plantation, Fort Belvoir Military Base, locations of the three shoreline cliff faces referred to in this report (High Point, Visitor Center, and Sycamore Point) and an outcrop of surficial gravel mentioned in the report (white circle). Blue arrows indicate creek/river flow direction. Abbreviations: Ck, Creek; GN, geographic north; MLS, Maryland Land Survey; MN, magnetic north. 


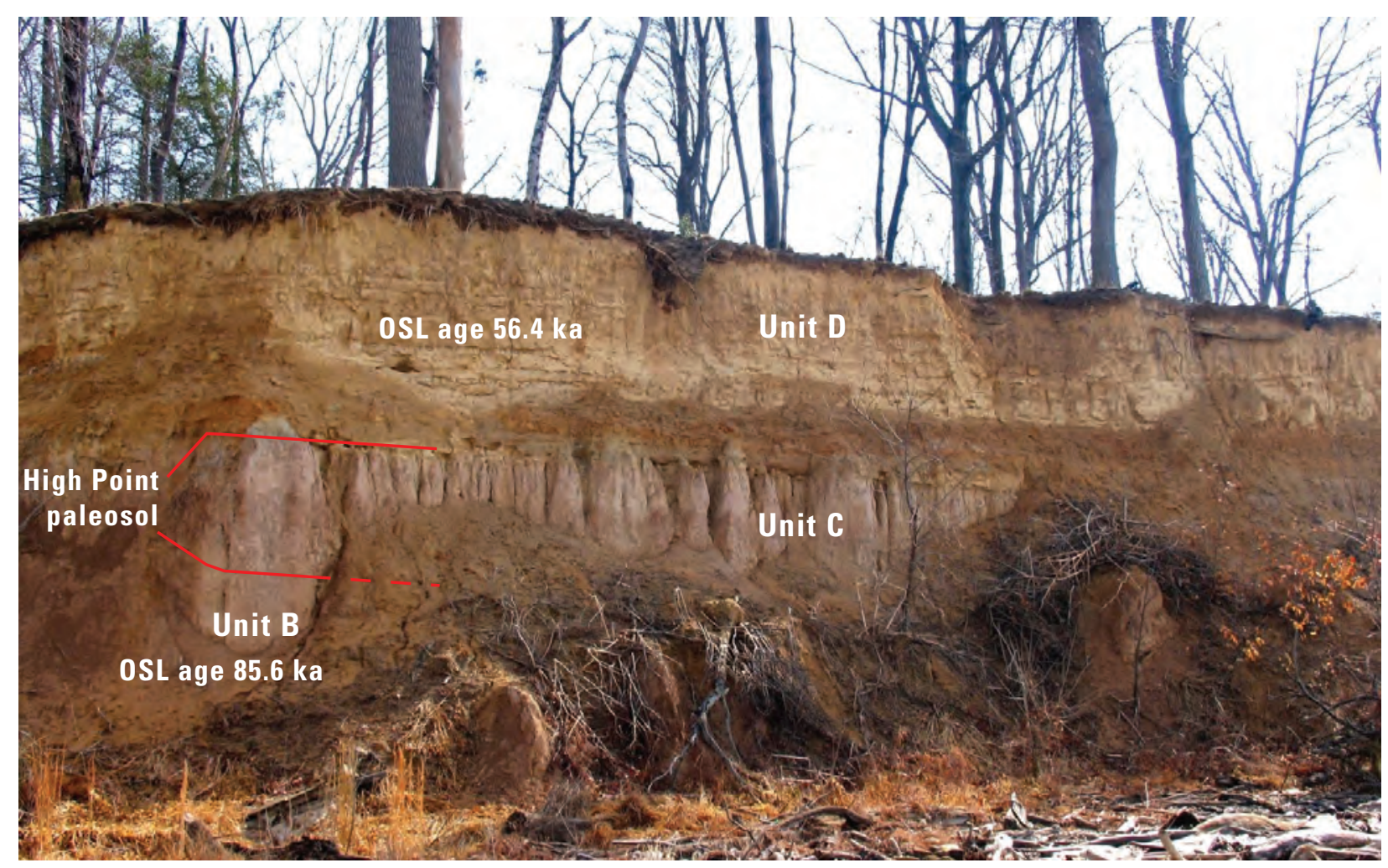

Figure 3. Photograph of the shoreline cliff face at the High Point locality showing optically stimulated luminescence (OSL) ages of Units B and D and the stratigraphic position of the High Point paleosol in Unit C. Abbreviation: ka, thousand years ago. Photograph taken by Helaine W. Markewich, U.S. Geological Survey. 
$\boldsymbol{A}$

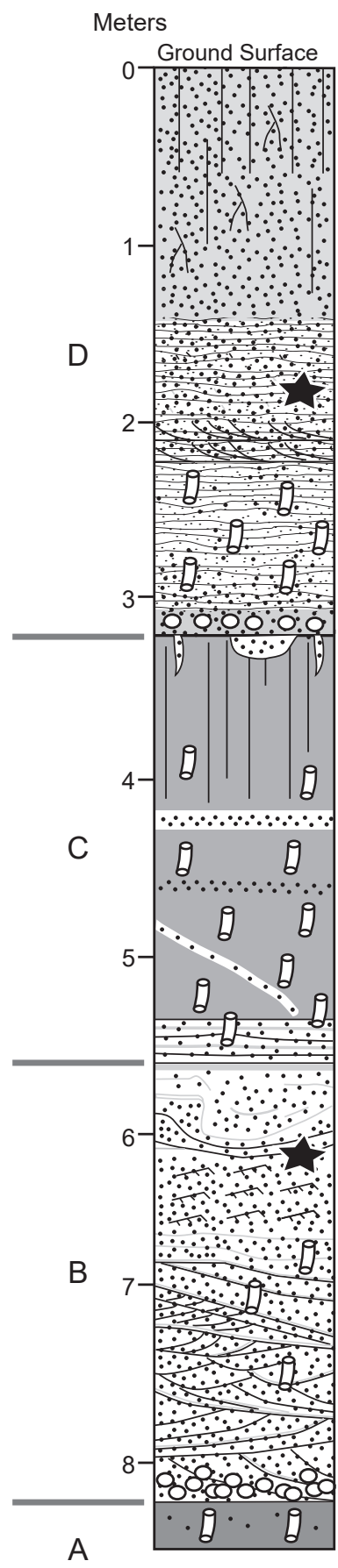

Mason Neck High Point stratigraphy, as taken from a Potomac River cliff-face exposure on Belmont Bay side of High Point (lat $38.6219^{\circ} \mathrm{N}$. , long $77.2050^{\circ} \mathrm{W}$.)

0-320 cm (Unit D). Upper $150 \mathrm{~cm}$ is heavily modified by roots and modern pedogenesis. Interbedded sand and silt in horizontal layers with cylindrical burrows underlie the soil. An OSL date from $\sim 180 \mathrm{~cm}$ depth is $56.4 \pm 6.0 \mathrm{ka}$. A $10-$ to $15-\mathrm{cm}$-thick layer of fine, orange, clayey sand marks the boundary between units $\mathrm{D}$ and $\mathrm{C}$. The sand contains scattered pebbles and cobble sand that is incorporated into deformation features that include bowl-shaped pods and sand dikes that project downward from the base of unit $D$ into unit $C$.

320-560 cm (Unit C). Strongly developed soil/paleosol in sandy, silty clay and clayey silt above a prominent, thin, horizontal sand bed. The soil is dominanty a maroon clayey silt with strong prismatic structure. A thin sand layer grades downward into a $100-\mathrm{cm}$-thick massive layer of clayey silt with abundant burrows and mottles. Irregular low-angle inclined sand dikes cut across the layer of clayey silt from the overlying thin sand bed into the basal layer of thin-bedded silt and clay. The basal contact of unit $\mathrm{C}$ is flat, beneath laterally continuous fine sand with no internal structure.

560-820 cm (Unit B). An upward-fining sequence from pebbly sand at the base to silty clay at the top. The basal sediments are coarse pebbly sand dominated by decimeterscale trough crossbedding with numerous clay drapes within foresets and between troughs. The sand becomes finer grained and trough crossbeds become progressively smaller upwards and have interbeds of climbing-ripple cross-lamination with abundant clay drapes. 100-200 cm above the base of the unit, fine sand beds are dominated by climbing-ripple cross-lamination with internal clay drapes and silty mud interbeds. Bioturbation becomes more abundant upward. The uppermost beds are alternating silt and silty clay with abundant burrow structures and little internal bedding. The uppermost $10-20 \mathrm{~cm}$ is clay with abundant silt- and sand-filled cracks, burrows, root casts, and prismatic parting. An OSL date of $85.6 \pm 11.4 \mathrm{ka}$ is from $\sim 230 \mathrm{~cm}$ above the base of the stratigraphic section.

820-860 cm (Unit A). Gray to dark gray, bioturbated, organic rich silt-clay. The pollen assemblage from this unit indicates an open forest dominated by oak $(37 \%)$, with subordinate pine $(9 \%)$ and hickory (3\%). Minor forest taxa included birch, beech, hophornbeam, poplar, elm, and juniper. A significant component of this flora was nonarboreal taxa, which included composites (35\%), grasses (4\%), alder, ferns, and sedges. These nonarboreal components suggest that some open meadow existed near the site at the time of deposition.

Figure 4. $A$, Generalized stratigraphy and optically stimulated luminescence (OSL) ages for the sedimentary sequence exposed in the shoreline cliff face at the High Point locality. $B$, Explanation of colors, patterns, and symbols for part $A$. Note that the explanation shown in $B$ is also for figures 5 and 6 . Abbreviations: $\mathrm{cm}$, centimeters; ka, thousand years ago; lat, latitude; long, longitude; \%, percent. 
EXPLANATION
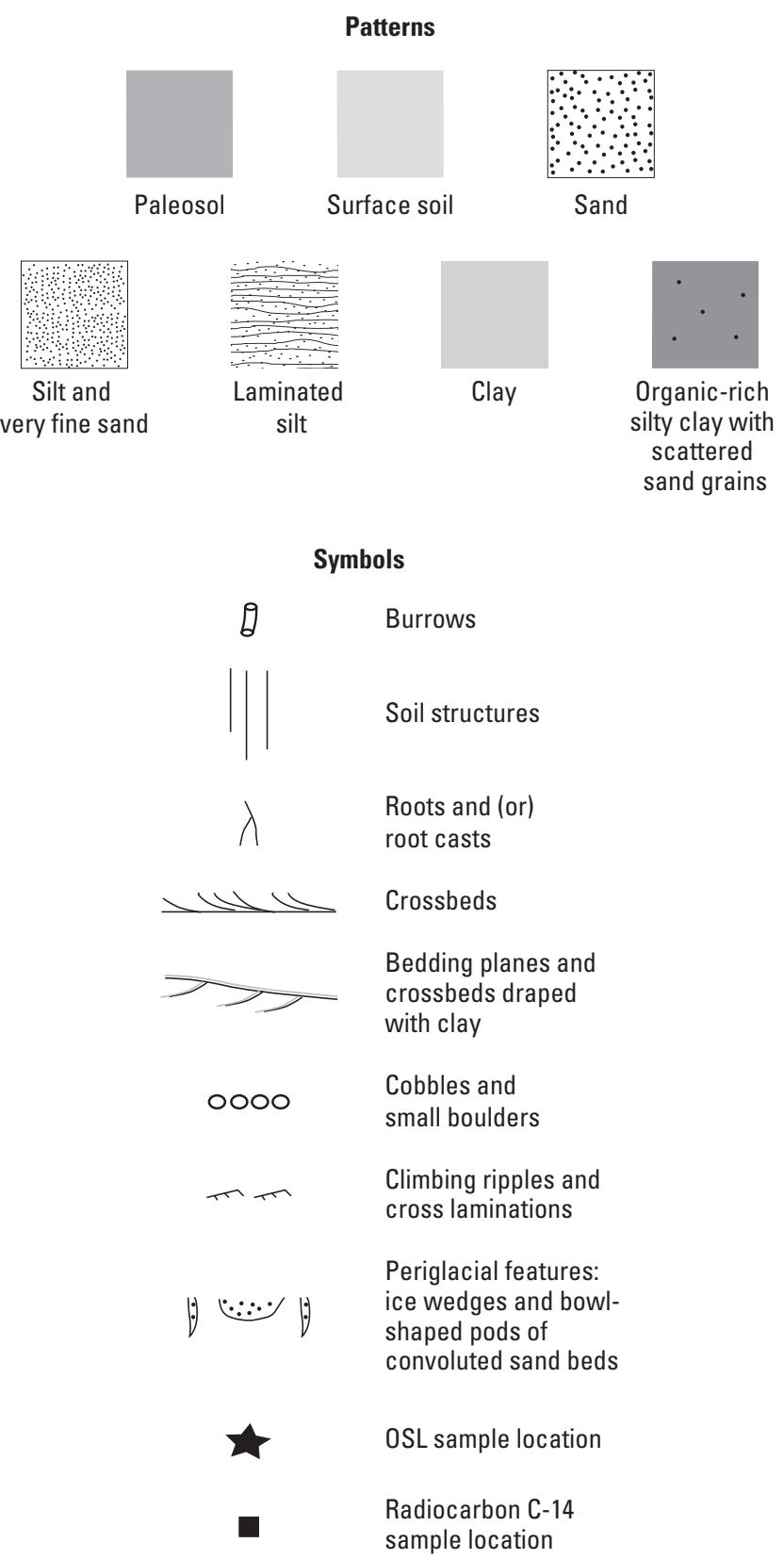

Figure 4.-Continued 


\author{
Mason Neck Visitor Center stratigraphy, \\ as taken from a Belmont Bay cliff-face exposure \\ (lat $38.6461^{\circ} \mathrm{N}$. , long $77.1978^{\circ} \mathrm{W}$.)
}

0-220 cm (Unit D). A fining upward sequence of pebbly sand to sandy silt. Bedding is horizontal. Unit $D$ at this site is very similar to unit $D$ at High Point (fig. 4) and very similar to Unit B in this outcrop and at High Point, but Unit D at this site appears to be finer-grained and contains more continuous mud partings. An OSL date of $58.2 \pm 7.9 \mathrm{ka}$ is from $\sim 190 \mathrm{~cm}$ depth.
220-320 cm (Unit C). A flat, laterally continuous basal layer of fine sand with no internal structure grading upward to gray clay with abundant burrows. Its basal contact truncates a number of bowl-shaped pods of deformed silt and clay projecting downward into the underlying clay of Unit B. This clay in the upper part of Unit $C$ also appears to have been altered by a period of dryness with permafrost. Sand-filled burrows and cracks occur at the top of this unit.

$320-780 \mathrm{~cm}$ (Unit B). A fining upward sequence of pebbly sand (with intraclasts eroded from Unit A) grading up to silty clay. Its lowest $2 \mathrm{~m}(580-780 \mathrm{~cm}$ depth) has decimeterscale trough crossbedded sand with abundant clay drapes of foresets and clay partings. The next meter (480-580 cm depth) is dominated by climbing-ripple cross-laminations with abundant clay drapes and interbeds. The upper $1.6 \mathrm{~m}$ (320-480 cm depth) is composed of alternations of bioturbated silt and silty mud with prismatic structure and root casts at top. Decimeter-scale deformed bowl-shaped sediment lenses occur beneath the contact with unit C. An OSL date of $67.0 \pm 8.0 \mathrm{ka}$ is from $\sim 720 \mathrm{~cm}$ depth.

$780-800 \mathrm{~cm}$ (Unit A ). A dark gray silty mud with pieces of carbonaceous material and abundant bioturbation.

Figure 5. Generalized stratigraphy and optically stimulated luminescence (OSL) ages for the sedimentary sequence exposed in the shoreline cliff face at the Visitor Center locality. For the explanation of colors, patterns, and symbols see figure 4B. Abbreviations: cm, centimeters; ka, thousand years ago; lat, latitude; long, longitude. 
Mason Neck Sycamore Point generalized stratigraphy, a composite of two Potomac River cliff-face exposures located about 10 meters apart (lat $38.6247^{\circ} \mathrm{N}$., long $77.1714^{\circ} \mathrm{W}$.)

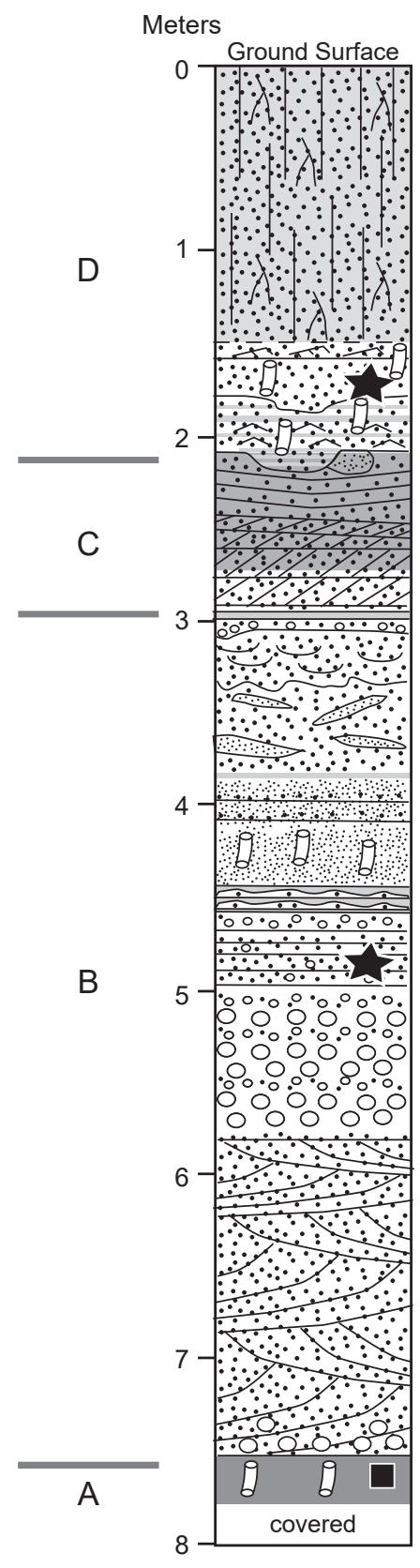

0-220 cm (Unit D). Horizontally laminated silty sands grading up from crossbedded sand. Strong prismatic soil. An OSL date of $54.0 \pm 8.0 \mathrm{ka}$ is from $\sim 170 \mathrm{~cm}$ depth.

220-300 cm (Unit C). Soil zone that contains permafrost features. Large ice-rafted(?) boulder (40-cm-long diameter) sits in soil at the contact with unit $D$.
300-760 cm (Unit B). In one exposure, the section of the cliff-face from $580-800 \mathrm{~cm}$ depth was debris covered. In the other exposure, a $50-\mathrm{cm}$-thick coarse sand and gravel marks the contact with unit $A$ at $760 \mathrm{~cm}$ depth. This gravel grades upward to an alternating sequence of gravel and fine-grained, crossbedded sand with localized areas of silty sand interbeds and bioturbation. An OSL date of $64.9 \pm 9.4 \mathrm{ka}$ is from $\sim 485 \mathrm{~cm}$ depth.

Figure 6. Generalized stratigraphy and optically stimulated luminescence (OSL) ages for the sedimentary sequence exposed in the shoreline cliff face at the Sycamore Point locality. For the explanation of colors, patterns, and symbols see figure 4B. Abbreviations: $14 C$, carbon- $14 ; \mathrm{cm}$, centimeters; ka, thousand years ago; lat, latitude; long, longitude; msl, mean sea level; USGS, U.S. Geological Survey. 
Table 1. Optically stimulated luminescence (OSL) ages for late Pleistocene quartz-rich sand samples exposed in shoreline cliff faces of Mason Neck, Virginia.

[Site locations are shown in figure 2. Assumed water content, $10 \% \pm 5 \%$; cosmic rate, $150 \pm 30 \mu \mathrm{Gy} / \mathrm{yr}$ (microgray/year). Abbreviations: N., north; W., west; msl, mean sea level; $\mathrm{U}$, uranium; ppm, parts per million; Th, thorium; K, potassium; \%, percent; Gy/ka, gray per thousand years; ka, thousand years ago; UGA, University of Georgia; Fm, Formation; *, data not available]

\begin{tabular}{|c|c|c|c|c|c|c|c|c|c|c|c|}
\hline $\begin{array}{l}\text { Location and } \\
\text { mapped strati- } \\
\text { graphic } \\
\text { unit }^{\mathrm{a}}\end{array}$ & $\begin{array}{l}\text { Latitude }^{b} \\
\text { (N.) }\end{array}$ & $\begin{array}{l}\text { Longitude }^{\mathrm{b}} \\
\text { (W.) }\end{array}$ & $\begin{array}{l}\text { Sample } \\
\text { elevation } \\
\text { (meters } \\
\text { relative } \\
\text { to } \mathrm{msl}^{\mathrm{c}} \text { ) }\end{array}$ & $\underset{(p p m)}{U}$ & $\begin{array}{c}\text { Th } \\
\text { (ppm) }\end{array}$ & $\begin{array}{c}K \\
(\%)\end{array}$ & $\begin{array}{c}\text { Dose rate } \\
(\text { Gy/ka) }\end{array}$ & $\begin{array}{c}\text { Mean } \\
\text { paleodose } \\
(G y)\end{array}$ & $\begin{array}{c}\text { OSL age } \\
\text { (ka) }\end{array}$ & Note & $\begin{array}{l}\text { UGA lab } \\
\text { number }^{\mathrm{e}}\end{array}$ \\
\hline $\begin{array}{l}\text { High Point, } \\
\text { Mason Neck, } \\
\text { Virginia; } \\
\text { Shirley Fm }\end{array}$ & 38.6219 & 77.2050 & 2.3 & $*$ & $*$ & $*$ & $*$ & $*$ & $85.6 \pm 11.4$ & $\begin{array}{l}\text { Sample from } \\
\text { unit B } \\
\text { below } \\
\text { paleosol }\end{array}$ & $\begin{array}{l}\text { UGA07 } \\
\text { OSL-519 }\end{array}$ \\
\hline $\begin{array}{l}\text { High Point, } \\
\text { Mason Neck, } \\
\text { Virginia; } \\
\text { Shirley Fm }\end{array}$ & 38.6219 & 77.2050 & 6.8 & $*$ & $*$ & $*$ & $*$ & $*$ & $56.4 \pm 6$ & $\begin{array}{l}\text { Sample from } \\
\text { unit D } \\
\text { above } \\
\text { paleosol }\end{array}$ & $\begin{array}{l}\text { UGA07 } \\
\quad \text { OSL-520 }\end{array}$ \\
\hline $\begin{array}{l}\text { Visitor Center, } \\
\text { Mason Neck, } \\
\text { Virginia; } \\
\text { Shirley Fm }\end{array}$ & 38.6461 & 77.1978 & 1 & $1.82 \pm 0.38$ & $5.03 \pm 1.31$ & 0.85 & $1.6 \pm 0.2$ & $107.23 \pm 7.45$ & $67.0 \pm 8.0$ & $\begin{array}{l}\text { Sample from } \\
\text { unit B } \\
\text { below } \\
\text { paleosol }\end{array}$ & $\begin{array}{l}\text { UGA09 } \\
\text { OSL-628 }\end{array}$ \\
\hline $\begin{array}{l}\text { Visitor Center, } \\
\text { Mason Neck, } \\
\text { Virginia; } \\
\text { Shirley Fm }\end{array}$ & 38.6461 & 77.1978 & 7 & $1.18 \pm 0.22$ & $2.95 \pm 0.78$ & 0.5 & $1.0 \pm 0.1$ & $59.68 \pm 5.96$ & $58.2 \pm 7.9$ & $\begin{array}{l}\text { Sample from } \\
\text { unit D } \\
\text { above } \\
\text { paleosol }\end{array}$ & $\begin{array}{l}\text { UGA09 } \\
\text { OSL-627 }\end{array}$ \\
\hline $\begin{array}{l}\text { Sycamore } \\
\text { Point, } \\
\text { Mason Neck, } \\
\text { Virginia; } \\
\text { Shirley Fm }\end{array}$ & 38.6247 & 77.1714 & 3 & $1.43 \pm 0.28$ & $4.43 \pm 0.99$ & 0.67 & $1.3 \pm 0.1$ & $85.81 \pm 9.62$ & $64.9 \pm 9.4$ & $\begin{array}{l}\text { Sample from } \\
\text { unit B } \\
\text { below } \\
\text { paleosol }\end{array}$ & $\begin{array}{l}\text { UGA09 } \\
\text { OSL-626 }\end{array}$ \\
\hline $\begin{array}{l}\text { Sycamore } \\
\text { Point, } \\
\text { Mason Neck, } \\
\text { Virginia; } \\
\text { Shirley Fm }\end{array}$ & 38.6247 & 77.1714 & 4.7 & $2.56 \pm 0.59$ & $6.71 \pm 2.02$ & 0.87 & $1.9 \pm 0.2$ & $102.28 \pm 9.48$ & $54.0 \pm 8.0$ & $\begin{array}{l}\text { Sample from } \\
\text { unit D } \\
\text { above } \\
\text { paleosol }\end{array}$ & $\begin{array}{l}\text { UGA09 } \\
\text { OSL-625 }\end{array}$ \\
\hline
\end{tabular}

${ }^{\mathrm{a}}$ Mapped stratigraphic unit, Shirley Formation (Fm).

${ }^{b}$ Decimal degrees, World Geodetic System 1984 (WGS84).

${ }^{c}$ Mean sea level (msl) is the datum for measurement of elevation and altitude and is the equipotential surface of the Earth as described by the WGS84 geoid.

dAlthough by convention the abbreviation "ka" is considered an age (thousand years ago), dose rate data for OSL dating generally is reported as Gy/ka (gray per thousand years), where "ka" is used as a duration of time. Here, dose rate data are reported as received from the laboratory.

${ }^{\text {e}}$ Dating for samples from Mason Neck was done by the University of Georgia (UGA) Luminescence Dating Laboratory (Athens, Georgia) using OSL techniques. For OSL laboratory analytical methods, see Mallinson and others (2008). 


\section{Pedostratigraphy and Age of the High Point Paleosol}

Although paleosols are considered important stratigraphic markers and paleoclimatic indicators for Pleistocene-age eolian (sand and silt) deposits in the central United States and other parts of the world (Valentine and Dalrymple, 1976; Muhs, 2021; and references in these publications), paleosols developed in Atlantic Coastal Plain eolian deposits have had limited attention (for example, Markewich and others, 2015; Wah and others, 2018; and references in these publications). Paleosols developed in northern Chesapeake Bay area eolian sediments (sand, silty sand, sandy silt, loess, water-lain loess) provide information on the region's paleoclimate both during and subsequent to deposition. Characteristics of these paleosols also provide data for development of a regional late-Pleistocene chronostratigraphic framework and a comprehensive paleoclimatic model. Wah and others (2018) provided a summary of MIS3 and MIS2 ( 40-13 ka) loess and associated paleosols on the Delmarva Peninsula in the northern Chesapeake Bay area. They also recorded the presence of mostly unstudied loess deposits west of Chesapeake Bay. They noted that in the Washington, D.C. area, these loess deposits are 50- to $95-\mathrm{cm}$-thick and cover almost every relatively flat, undisturbed land surface at elevations between $6 \mathrm{~m}$ and $50 \mathrm{~m}$ above sea level. Feldman and others (2000) studied the stratigraphy of an $\sim 13 \mathrm{ka}$ (MIS2) loess deposit and the included paleosol that is located in the Potomac River valley on an interfluve about $33 \mathrm{~km}$ southwest of Washington, D.C. and $12.5 \mathrm{~km}$ northwest of the Mason Neck (location not shown in this report).

Pavich and others (2010) and Wysocki and others (2010) presented age data for the Mason Neck sedimentary sequence (figs. 4-6) and pedologic data for the paleosol exposed in a Mason Neck shoreline cliff face near High Point (fig. 7). Their reports were the first that recognized late MIS5a and MIS4 loess deposition and paleosol development in the Potomac River valley. They informally referred to the paleosol as the High Point paleosol. Unit $\mathrm{C}$ of the Mason Neck sedimentary sequence, including the High Point paleosol, is thickest at the High Point locality. The High Point paleosol also is thickest and best developed at this locality. The stratigraphic position and bracketing ages of the High Point paleosol are shown in figures 3 and 4. Photographs of the High Point paleosol are in figures $3,7 A$, and $7 B$. Selected laboratory data (particle size, bulk density, water content) for the paleosol are included in tables 2 and 4. Particle-size ratios (fine clay to total clay, fine silt to coarse silt, and very fine sand to fine sand) are in table 3. Selected major-element ratios (silica to aluminum, silica to titanium, magnesium to calcium, phosphorus to calcium, phosphorus to titanium) are in table 5. Clay mineralogy is in table 6 and selected trace-element data are in table 7.

The High Point paleosol description in the following paragraphs is for the High Point shoreline cliff face exposure. The description uses the terminology of the 1993 edition of the "Soil Survey Manual" (in the References Cited as Soil Science Division Staff [2017]) and the terminology and field methods described in Schoeneberger and others (2003). The horizon textures in the description were determined in the field and subsequently in the laboratory from particle size analysis. In the paleosol description, horizon texture as determined from particle size analysis is given in brackets. Selected laboratory data for the paleosol are in tables 2 to 5 . These and other laboratory data for the High Point paleosol can be accessed online in the National Cooperative Soil Survey Soil Characterization Database (National Cooperative Soil Survey, undated) by using the user pedon ID SVA059001.

\section{High Point Paleosol Site Description}

Date: April 14, 2010.

Weather and temperature: sunny and warm, 17 to $24^{\circ} \mathrm{C}$.

General location: High Point, Mason Neck, Fairfax County, Virginia; lat $38.6219^{\circ} \mathrm{N}$., long $77.2050^{\circ} \mathrm{W}$. (WGS); Indian Head, Maryland, 7.5-degree topographic quadrangle.

Site location: 8- to 10-m-high exposure in a shoreline cliff face of the Potomac River on the Occoquan Bay side of High Point promontory (figs. 2-4).

Vegetation: Black locust (Robinia pseudocacia), chinquapin (Quercus muehlenbergii), black cherry (Prunus serotina), and sweet gum (Liquidambar styraciflua) growing into bank on the cut face and in talus at slope breaks and at foot of cliff face.

Slope: cliff face; $\sim 3 \mathrm{~m}$ depth from top of cliff face to top of paleosol, paleosol exposure near vertical when stepped for footing and dugout for best exposure.

Parent material: river floodplain and (or) eolian silt and silt loam with water-lain characteristics, overlying (grading upward from) estuarine sand.

Datum: top of paleosol is the contact between the leached Eg horizon at the top of Unit $\mathrm{C}$ and the overlying oxidized "orange" sand of Unit D (fig. 7C). 


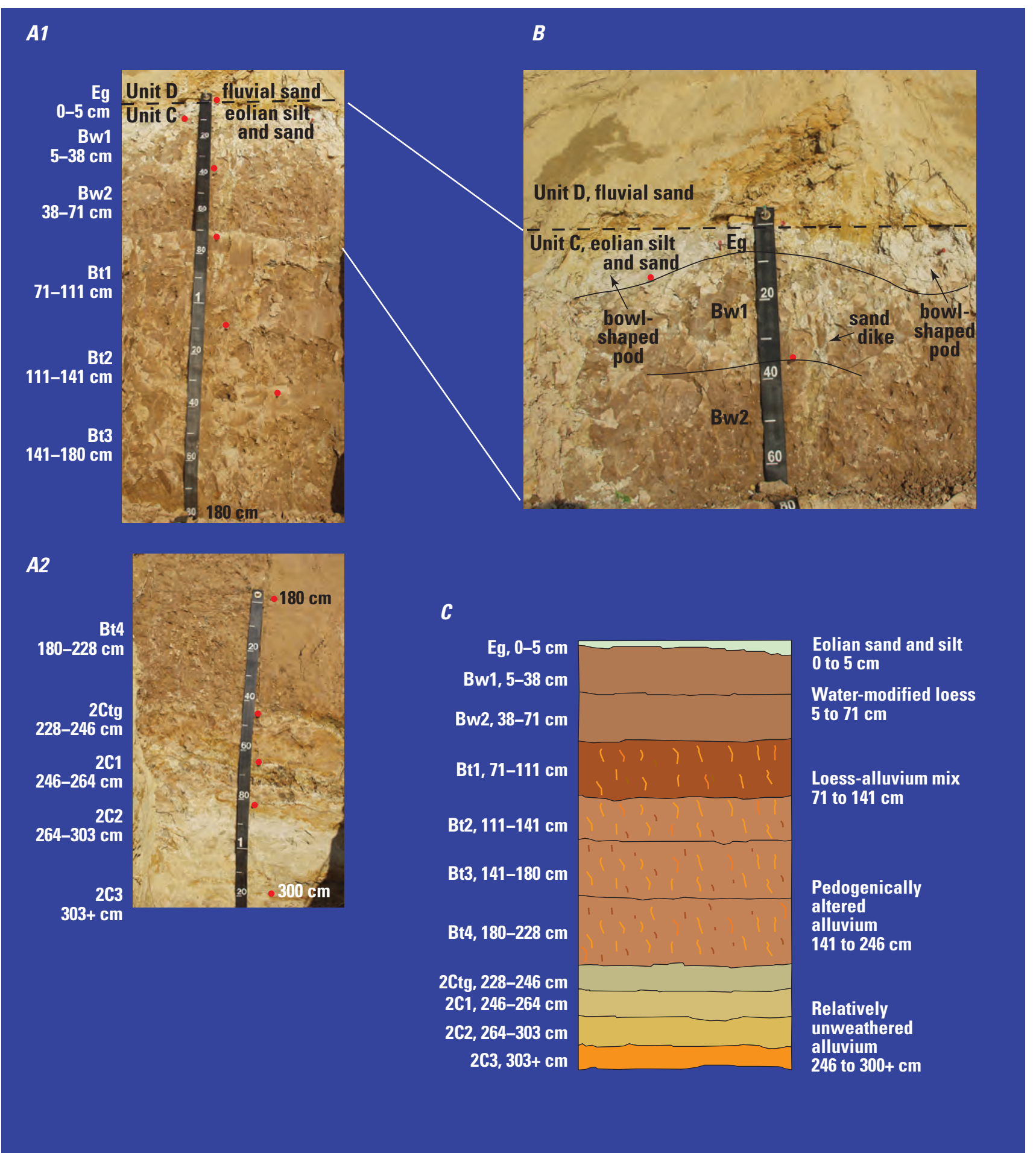

Figure 7. Photographs and pedostratigraphy (parts $A 1, A 2$, and $B$ ) and lithostratigraphy (part $C$ ) of the High Point paleosol, described and sampled from the High Point shoreline cliff-face locality, Mason Neck, Virginia. Part $C$ shows the pedostratigraphy and parent material of the High Point paleosol. Part $A 2$ is a continuation of the soil profile in the part A1. All soil horizon designations (for example, Eg, Bw, Bt, 2C, 2Ctg) are according to Schoeneberger and others (2003). Red dots indicate the upper boundary of the paleosol and boundaries between two soil horizons in the soil profile. Short, variegated lines in part $C$ indicate lithostratigraphic horizons that have prismatic and blocky soil structure. Abbreviation: cm, centimeters. Photographs taken by Douglas A. Wysocki, National Resources Conservation Service. 
Table 2. Particle size distribution in weight percent for the High Point paleosol exposed in the High Point shoreline cliff face, Mason Neck, Virginia.

[Location is shown in figure 2; lat $38.6219^{\circ} \mathrm{N}$., long $77.2050^{\circ} \mathrm{W}$. Abbreviations: cm, centimeters; mm, millimeters; -, none measured; tr, trace]

\begin{tabular}{|c|c|c|c|c|c|c|c|c|c|c|c|c|c|c|c|}
\hline $\begin{array}{c}\text { Horizon } \\
\text { and } \\
\text { parent } \\
\text { material }\end{array}$ & $\begin{array}{c}\text { Horizon } \\
\text { depth } \\
\text { interval } \\
(\mathrm{cm})^{\mathrm{a}}\end{array}$ & $\begin{array}{l}\text { Midpoint } \\
\text { depth } \\
\text { (cm) }\end{array}$ & $\begin{array}{c}\text { Clay } \\
<0.002 \\
(\mathrm{~mm})\end{array}$ & $\begin{array}{c}\text { Silt } \\
0.002- \\
0.05 \\
(\mathrm{~mm})\end{array}$ & $\begin{array}{c}\text { Sand } \\
0.05-2.0 \\
(\mathrm{~mm})\end{array}$ & $\begin{array}{c}\text { Fine clay } \\
<0.0002 \\
(\mathrm{~mm})\end{array}$ & $\begin{array}{c}\text { Fine silt } \\
0.002- \\
0.02 \\
(\mathrm{~mm})\end{array}$ & $\begin{array}{c}\text { Coarse } \\
\text { silt } \\
0.02-0.05 \\
(\mathrm{~mm})\end{array}$ & $\begin{array}{l}\text { Very fine } \\
\text { sand } \\
0.05-0.1 \\
\text { (mm) }\end{array}$ & $\begin{array}{c}\text { Fine } \\
\text { sand } \\
0.1-0.25 \\
(\mathrm{~mm})\end{array}$ & $\begin{array}{l}\text { Medium } \\
\text { sand } \\
0.25-0.5 \\
(\mathrm{~mm})\end{array}$ & $\begin{array}{c}\text { Coarse } \\
\text { sand } \\
0.5-1.0 \\
(\mathrm{~mm})\end{array}$ & $\begin{array}{c}\text { Very } \\
\text { coarse } \\
\text { sand } \\
1.0-2.0 \\
(\mathrm{~mm})\end{array}$ & $\begin{array}{l}0.1-75 \\
(\mathrm{~mm})^{\mathrm{b}}\end{array}$ & $\begin{array}{c}>2.0 \\
(\mathrm{~mm})^{\mathrm{c}}\end{array}$ \\
\hline $\begin{array}{l}\text { Eg, } \\
\text { loess- } \\
\text { eolian } \\
\text { sand }\end{array}$ & $0-5$ & 2.5 & 17.9 & 46.5 & 35.6 & 7.3 & 24.7 & 21.8 & 20.3 & 14 & 1.2 & 0.1 & - & 16 & 1 \\
\hline $\begin{array}{l}\text { Bw1, } \\
\text { water- } \\
\text { lain } \\
\text { loess }\end{array}$ & 5-38 & 21.5 & 36.1 & 54.9 & 9.0 & 14.0 & 36.7 & 18.2 & 7.4 & 1.4 & 0.1 & $\operatorname{tr}$ & 0.1 & 2 & - \\
\hline $\begin{array}{l}\text { Bw2, } \\
\quad \text { water- } \\
\text { lain } \\
\text { loess }\end{array}$ & $38-71$ & 54.5 & 32.4 & 51.9 & 15.7 & 13.7 & 32.4 & 19.5 & 13.8 & 1.8 & 0.1 & - & - & 2 & - \\
\hline $\begin{array}{l}\text { Bt1, } \\
\text { loess- } \\
\text { alluvium }\end{array}$ & $71-91$ & 81.0 & 26 & 47.4 & 26.6 & 11.7 & 26.0 & 21.4 & 22.1 & 4.4 & 0.1 & - & - & 5 & - \\
\hline $\begin{array}{l}\text { Bt1, } \\
\text { loess- } \\
\text { alluvium }\end{array}$ & $91-111$ & 101.0 & 24.6 & 45.9 & 29.5 & 10.2 & 26.4 & 19.5 & 21.9 & 7.4 & 0.2 & $\operatorname{tr}$ & - & 8 & - \\
\hline $\begin{array}{l}\text { Bt2, } \\
\text { loess- } \\
\text { alluvium }\end{array}$ & $111-141$ & 126.0 & 25.6 & 49.0 & 25.4 & 10.3 & 28.2 & 20.8 & 17.9 & 7.3 & 0.1 & - & 0.1 & 8 & - \\
\hline $\begin{array}{l}\text { Bt3, } \\
\quad \text { alluvium }\end{array}$ & $141-161$ & 151.0 & 22 & 39.3 & 38.7 & 8.5 & 21.6 & 17.7 & 23.6 & 14.9 & 0.2 & $\operatorname{tr}$ & - & 15 & - \\
\hline $\begin{array}{l}\text { Bt3, } \\
\quad \text { alluvium }\end{array}$ & $161-180$ & 170.5 & 19.4 & 39.8 & 40.8 & 7.4 & 22.8 & 17.0 & 21.5 & 18.6 & 0.4 & 0.2 & 0.1 & 19 & - \\
\hline $\begin{array}{l}\text { Bt4, } \\
\quad \text { alluvium }\end{array}$ & $180-204$ & 192.0 & 14.7 & 37.1 & 48.2 & 5.1 & 20.5 & 16.6 & 22.7 & 25.4 & 0.1 & - & - & 26 & - \\
\hline $\begin{array}{l}\text { Bt4, } \\
\quad \text { alluvium }\end{array}$ & 204-228 & 216.0 & 14.7 & 36.5 & 48.8 & 5.6 & 21.0 & 15.5 & 21.4 & 26.6 & 0.7 & 0.1 & - & 27 & - \\
\hline $\begin{array}{l}2 \mathrm{Ctg} \\
\text { alluvium }\end{array}$ & $228-246$ & 237.0 & 16.6 & 13.4 & 70.0 & 10.3 & 7.6 & 5.8 & 21.5 & 45.3 & 2.9 & 0.2 & 0.1 & 49 & - \\
\hline $\begin{array}{l}2 \mathrm{C} 1, \\
\quad \text { alluvium }\end{array}$ & $246-264$ & 255.0 & 13.2 & 16.2 & 70.6 & 8.3 & 8.6 & 7.6 & 19.4 & 46.2 & 4.5 & 0.4 & 0.1 & 51 & - \\
\hline
\end{tabular}


[Location is shown in figure 2; lat $38.6219^{\circ} \mathrm{N}$., long $77.2050^{\circ} \mathrm{W}$. Abbreviations: $\mathrm{cm}$, centimeters; mm, millimeters; -, none measured; tr, trace]

\begin{tabular}{|c|c|c|c|c|c|c|c|c|c|c|c|c|c|c|c|}
\hline $\begin{array}{l}\text { Horizon } \\
\text { and } \\
\text { parent } \\
\text { material }\end{array}$ & $\begin{array}{c}\text { Horizon } \\
\text { depth } \\
\text { interval } \\
(\mathrm{cm})^{\mathrm{a}}\end{array}$ & $\begin{array}{l}\text { Midpoint } \\
\text { depth } \\
(\mathrm{cm})\end{array}$ & $\begin{array}{c}\text { Clay } \\
<0.002 \\
(\mathrm{~mm})\end{array}$ & $\begin{array}{c}\text { Silt } \\
0.002- \\
0.05 \\
(\mathrm{~mm})\end{array}$ & $\begin{array}{c}\text { Sand } \\
0.05-2.0 \\
(\mathrm{~mm})\end{array}$ & $\begin{array}{c}\text { Fine clay } \\
<0.0002 \\
(\mathrm{~mm})\end{array}$ & $\begin{array}{c}\text { Fine silt } \\
0.002- \\
0.02 \\
(\mathrm{~mm})\end{array}$ & $\begin{array}{c}\text { Coarse } \\
\text { silt } \\
0.02-0.05 \\
\text { (mm) }\end{array}$ & $\begin{array}{c}\text { Very fine } \\
\text { sand } \\
0.05-0.1 \\
\text { (mm) }\end{array}$ & $\begin{array}{c}\text { Fine } \\
\text { sand } \\
0.1-0.25 \\
(\mathrm{~mm})\end{array}$ & $\begin{array}{l}\text { Medium } \\
\text { sand } \\
0.25-0.5 \\
(\mathrm{~mm})\end{array}$ & $\begin{array}{c}\text { Coarse } \\
\text { sand } \\
0.5-1.0 \\
(\mathrm{~mm})\end{array}$ & $\begin{array}{c}\text { Very } \\
\text { coarse } \\
\text { sand } \\
1.0-2.0 \\
(\mathrm{~mm})\end{array}$ & $\begin{array}{l}0.1-75 \\
(\mathrm{~mm})^{b}\end{array}$ & $\begin{array}{l}>2.0 \\
(\mathrm{~mm})^{\mathrm{c}}\end{array}$ \\
\hline $\begin{array}{l}2 \mathrm{C} 2, \\
\quad \text { alluvium }\end{array}$ & 264-284 & 274.0 & 7.1 & 9.9 & 83.0 & 4.3 & 5.2 & 4.7 & 19.1 & 59.3 & 4.6 & - & $\operatorname{tr}$ & 64 & - \\
\hline $\begin{array}{l}2 \mathrm{C} 3, \\
\quad \text { alluvium }\end{array}$ & $284-303$ & 293.5 & 13.1 & 18.2 & 68.7 & 7.6 & 10.3 & 7.9 & 14.8 & 49.3 & 3.8 & 0.6 & 0.2 & 54 & - \\
\hline
\end{tabular}

${ }^{a}$ Horizon depths are measured from the contact between the top of the paleosol and the overlying sand as shown in figure 7. Horizons Bt1, Bt3, Bt4, and 2C2 were subsampled.

${ }^{b}$ The gravimetric percentage of 0.1 - to 75 -mm-diameter particles is reported on a $<75 \mathrm{~mm}$ base.

${ }^{c}$ The weight fraction of particles with $>2$-mm diameter is reported as a gravimetric percent on a whole soil base. 
Table 3. Particle size ratios for the High Point paleosol exposed in the High Point shoreline cliff face, Mason Neck, Virginia.

[Location is shown in figure 2; lat $38.6219^{\circ} \mathrm{N}$., long $77.2050^{\circ} \mathrm{W}$. Abbreviation: cm, centimeters]

\begin{tabular}{|c|c|c|c|c|}
\hline $\begin{array}{c}\text { Horizon } \\
\text { designation }\end{array}$ & $\begin{array}{l}\text { Horizon depth interval } \\
(\mathbf{c m})^{\mathrm{a}}\end{array}$ & $\begin{array}{c}\text { Ratio of } \\
\text { fine clay } \\
\text { to } \\
\text { total clay }\end{array}$ & $\begin{array}{c}\text { Ratio of } \\
\text { fine silt } \\
\text { to } \\
\text { coarse silt }\end{array}$ & $\begin{array}{c}\text { Ratio of } \\
\text { very fine sand } \\
\text { to } \\
\text { fine sand }\end{array}$ \\
\hline $\begin{array}{l}\text { Eg, } \\
\text { loess-eolian sand }\end{array}$ & $0-5$ & 0.41 & 1.13 & 1.45 \\
\hline $\begin{array}{l}\text { Bw1, } \\
\quad \text { water-lain loess }\end{array}$ & $5-38$ & 0.39 & 2.02 & 5.29 \\
\hline $\begin{array}{l}\text { Bw2, } \\
\quad \text { water-lain loess }\end{array}$ & 38-71 & 0.42 & 1.66 & 7.67 \\
\hline $\begin{array}{l}\text { Bt1, } \\
\quad \text { loess-alluvium }\end{array}$ & 71-91 & 0.45 & 1.21 & 5.02 \\
\hline $\begin{array}{l}\text { Bt1, } \\
\text { loess-alluvium }\end{array}$ & $91-111$ & 0.41 & 1.35 & 2.96 \\
\hline $\begin{array}{l}\text { Bt2, } \\
\quad \text { loess-alluvium }\end{array}$ & 111-141 & 0.40 & 1.36 & 2.45 \\
\hline $\begin{array}{l}\text { Bt3, } \\
\quad \text { alluvium }\end{array}$ & $141-161$ & 0.39 & 1.22 & 1.58 \\
\hline $\begin{array}{l}\text { Bt3, } \\
\quad \text { alluvium }\end{array}$ & $161-180$ & 0.38 & 1.34 & 1.16 \\
\hline $\begin{array}{l}\text { Bt4, } \\
\quad \text { alluvium }\end{array}$ & 180-204 & 0.36 & 1.23 & 0.89 \\
\hline $\begin{array}{l}\text { Bt4, } \\
\quad \text { alluvium }\end{array}$ & 204-228 & 0.38 & 1.36 & 0.80 \\
\hline $\begin{array}{l}2 \mathrm{Ctg} \\
\quad \text { alluvium }\end{array}$ & $228-246$ & 0.62 & 1.31 & 0.47 \\
\hline $\begin{array}{l}2 \mathrm{C} 1, \\
\quad \text { alluvium }\end{array}$ & 246-264 & 0.63 & 1.13 & 0.42 \\
\hline $\begin{array}{l}2 \mathrm{C} 2 \\
\quad \text { alluvium }\end{array}$ & 264-284 & 0.61 & 1.11 & 0.32 \\
\hline $\begin{array}{l}2 \mathrm{C} 3, \\
\quad \text { alluvium }\end{array}$ & 284-303 & 0.68 & 1.30 & 0.30 \\
\hline
\end{tabular}

${ }^{\text {a} H o r i z o n ~ d e p t h s ~ a r e ~ m e a s u r e d ~ f r o m ~ t h e ~ c o n t a c t ~ b e t w e e n ~ t h e ~ t o p ~ o f ~ t h e ~ p a l e o s o l ~ a n d ~ t h e ~ o v e r l y i n g ~ s a n d ~ a s ~ s h o w n ~ i n ~ f i g u r e ~ 7 . ~ H o r i z o n s ~ B t 1, ~ B t 3, ~ B t 4, ~ a n d ~ 2 C 2 ~}$ were subsampled.

\section{High Point Paleosol Profile Description}

All colors in the paleosol description are for moist soil or sediment. Texture percentages in the profile description are estimates made in the field. Measured percentages and other laboratory data for the High Point paleosol (tables 2-7) were determined by the Kellogg Soil Survey Laboratory (Lincoln, Nebraska), and are available online in the National Cooperative Soil Survey Soil Characterization Database (National Cooperative Soil Survey, undated). Methods of soil analyses used by the Kellogg Soil Survey Laboratory are described in the laboratory methods manual (Burt and Natural Resources Conservation Service Soil Survey Staff, 2014). Data in tables 3 and 5 are as presented at the American Society of Agronomy, Crop Science Society of America, and Soil
Science Society of America 2010 International Annual Meetings (Wysocki and others, 2010).

Eg - 0-5 cm depth where measured; actual horizon thickness ranges from 5 to $15 \mathrm{~cm}$

$2.5 Y 6 / 2$; silt loam ( $18 \%$ clay, $50 \%$ silt, $32 \%$ very fine to fine sand); [loam]; massive; friable; slightly sticky, slightly plastic; clear irregular boundary; $5 \%$ medium and coarse, prominent, diffuse iron masses that are concentrated in the upper part of the horizon; few fine roots throughout; common (most are from vegetation growing on the cliff face), fine tubular pores throughout; upper surface of horizon is abrupt boundary; distance from trough to peak of the lower irregular boundary is 15 to $50 \mathrm{~cm} ; 1 \%-5 \%$; subrounded to subangular fine and medium gravel (2-20 
Table 4. Bulk density and water content data for the High Point paleosol exposed in the High Point shoreline cliff face, Mason Neck, Virginia.

[Location is shown in figure 2; lat $38.6219^{\circ} \mathrm{N}$., long $77.2050^{\circ} \mathrm{W}$. Abbreviations: cm, centimeters; $\mathrm{kPa}$, kilopascals ( $1 \mathrm{kPa}$ is equal to 0.14503773779 pounds per square inch); -, no data]

\begin{tabular}{|c|c|c|c|c|c|}
\hline $\begin{array}{c}\text { Horizon } \\
\text { designation }\end{array}$ & $\begin{array}{l}\text { Horizon depth } \\
\text { interval } \\
(\mathrm{cm})^{\mathrm{a}}\end{array}$ & $\begin{array}{l}\text { Bulk density } \\
\text { (33 kPa) }\end{array}$ & $\begin{array}{l}\text { Bulk density } \\
\text { (oven dry) }\end{array}$ & $\begin{array}{l}\text { Water } \\
\text { content } \\
(33 \mathrm{kPa})\end{array}$ & $\begin{array}{c}\text { Water } \\
\text { content } \\
(1,500 \mathrm{kPa})\end{array}$ \\
\hline $\begin{array}{l}\text { Eg, } \\
\quad \text { loess-eolian sand }\end{array}$ & $0-5$ & 1.61 & 1.68 & 18.7 & 7.1 \\
\hline $\begin{array}{l}\text { Bw1, } \\
\quad \text { water-lain loess }\end{array}$ & $5-38$ & 1.75 & 1.88 & 20.5 & 14.9 \\
\hline $\begin{array}{l}\text { Bt1, } \\
\text { loess-alluvium }\end{array}$ & $71-111$ & 1.62 & 1.68 & 24.3 & $10.5^{b}$ \\
\hline $\begin{array}{l}\text { Bt2, } \\
\text { loess-alluvium }\end{array}$ & $111-141$ & 1.57 & 1.64 & 19.5 & 10.3 \\
\hline $\begin{array}{l}2 \mathrm{Ctg}, \\
\text { alluvium }\end{array}$ & $228-246$ & - & - & - & 6.9 \\
\hline $\begin{array}{l}2 \mathrm{C} 1, \\
\quad \text { alluvium }\end{array}$ & $246-264$ & - & - & - & 5.0 \\
\hline $\begin{array}{l}2 \mathrm{C} 2, \\
\quad \text { alluvium }\end{array}$ & $264-284$ & - & - & - & 2.3 \\
\hline $\begin{array}{l}2 \mathrm{C} 3, \\
\quad \text { alluvium }\end{array}$ & $284-303$ & - & - & - & 5.4 \\
\hline
\end{tabular}

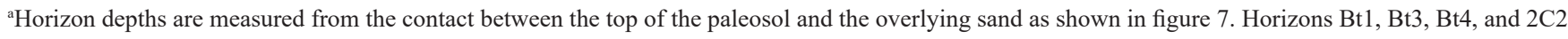
were subsampled.

${ }^{b}$ Water content values are an average of values for the horizon subsamples.

$\mathrm{mm}), 1 \%-2 \%$ coarse gravel $(20-75 \mathrm{~mm})$, and $1 \%$ cobbles $(75-250 \mathrm{~mm})$ scattered throughout but particularly near the upper boundary.

Bw1 - 5-38 cm depth

7.5 YR 5/4; silty clay loam (28\% clay, $55 \%$ silt, $13 \%$ very fine to fine sand); [silty clay loam]; very dense, massive, breaks with a conchoidal fracture; very firm; moderately sticky, moderately plastic; diffuse wavy boundary; $<2 \%$ distinct, fine and medium, 7.5YR 6/6 iron masses throughout and lining pores; few distinct fine and medium 10YR 2/1 manganese masses throughout and lining pores; iron also lines contemporary root channels therefore are at least in part modern; very few fine roots throughout and down desiccation cracks; very fine tubular pores throughout; infilling of $2.5 Y R$ 6/2 Eg-horizon material lining cracks and desiccation surfaces; no infilling from overlying oxidized sand (indicating the infilling is not a modern process).
Bw2 - 38-71 cm depth

7.5 YR 5/4; silty clay loam ( $28 \%$ clay, $55 \%$ silt, $13 \%$ very fine to fine sand); [silty clay loam]; weak, fine and medium subangular blocky; firm; moderately sticky, moderately plastic; diffuse, smooth boundary; common, distinct, fine and medium, 7.5YR 6/6 iron masses throughout and lining pores; few, fine and medium 10YR 2/1 manganese masses throughout; iron lines contemporary root channels (therefore is at least in part modern); very few fine roots throughout and down desiccation faces; very few fine tubular pores throughout; infilling of $2.5 Y 6 / 2 \mathrm{Eg}$-horizon material down desiccation surfaces; $2.5 Y 7 / 1$ material that is similar to the Eg horizon material down desiccation surfaces; no infilling from oxidized sands overlying the paleosol (indicating the infilling of Eg-horizon material is not a modern process).

Bt1 - 71-111 cm depth

$7.5 Y R$ 4/4; silty clay loam ( $28 \%$ clay, $50 \%$ silt, $22 \%$ very fine to fine sand); [loam]; weak very coarse prismatic breaking to 
Table 5. Major-element data ratios for the High Point paleosol exposed in the High Point shoreline cliff face, Mason Neck, Virginia.

[Location is shown in figure 2; lat $38.6219^{\circ} \mathrm{N}$., long $77.2050^{\circ} \mathrm{W}$. Abbreviations: cm, centimeters; Si, silica; Al, aluminum; Ti, titanium; Mg, magnesium; Ca, calcium; P, phosphorus]

\begin{tabular}{|c|c|c|c|c|c|c|c|}
\hline \multirow{2}{*}{$\begin{array}{c}\text { Horizon } \\
\text { designation }\end{array}$} & \multirow{2}{*}{$\begin{array}{l}\text { Horizon depth } \\
\text { interval } \\
(\mathbf{c m})^{\mathrm{a}}\end{array}$} & \multicolumn{6}{|c|}{ Major-element data ratios ${ }^{b}$} \\
\hline & & $\mathrm{Si} / \mathrm{Al} / 2$ & $\mathrm{Si} / \mathrm{Ti} / 10$ & $\mathrm{Mg} / \mathrm{Ca}$ & $\mathrm{Mg} / \mathrm{Ti} / 0.1$ & $\mathrm{P} / \mathrm{Ca} / 0.02$ & $\mathrm{P} / \mathrm{Ti} / 0.005$ \\
\hline $\begin{array}{l}\text { Eg, loess- } \\
\quad \text { eolian sand }\end{array}$ & $0-5$ & 3.6 & 6.2 & 3.0 & 5.5 & 6.0 & 4.4 \\
\hline $\begin{array}{c}\text { Bw1, water- } \\
\text { lain loess }\end{array}$ & $5-38$ & 2.2 & 4.8 & 4.2 & 8.3 & 6.2 & 4.9 \\
\hline $\begin{array}{c}\text { Bw2, water- } \\
\text { lain loess }\end{array}$ & $38-71$ & 2.3 & 5.0 & 3.4 & 8.8 & 5.4 & 5.6 \\
\hline $\begin{array}{l}\text { Bt1, loess- } \\
\text { alluvium }\end{array}$ & $71-91$ & 2.8 & 5.7 & 2.4 & 8.5 & 4.1 & 5.8 \\
\hline $\begin{array}{l}\text { Bt1, loess- } \\
\text { alluvium }\end{array}$ & $91-111$ & 3.0 & 5.8 & 2.4 & 8.1 & 3.7 & 4.9 \\
\hline $\begin{array}{l}\text { Bt2, loess- } \\
\text { alluvium }\end{array}$ & $111-141$ & 2.7 & 5.9 & 2.2 & 9.2 & 3.5 & 5.8 \\
\hline Bt3, alluvium & 141-161 & 3.3 & 6.2 & 2.0 & 8.1 & 3.5 & 5.9 \\
\hline Bt3, alluvium & $161-180$ & 3.5 & 6.1 & 1.7 & 7.7 & 3.0 & 5.4 \\
\hline Bt4, alluvium & 180-204 & 4.0 & 6.2 & 1.5 & 7.1 & 2.7 & 5.1 \\
\hline Bt4, alluvium & 204-228 & 4.0 & 6.3 & 1.4 & 7.2 & 2.4 & 4.8 \\
\hline $2 \mathrm{Ctg}$, alluvium & 228-246 & 4.6 & 7.7 & 1.4 & 6.7 & 3.6 & 6.9 \\
\hline 2C1, alluvium & 246-264 & 5.0 & 7.3 & 1.2 & 5.8 & 2.2 & 4.3 \\
\hline $2 \mathrm{C} 2$, alluvium & 264-284 & 7.3 & 8.0 & 0.8 & 3.9 & 2.1 & 4.1 \\
\hline $2 \mathrm{C} 3$, alluvium & 284-303 & 4.9 & 6.2 & 1.0 & 4.7 & 2.3 & 4.2 \\
\hline
\end{tabular}

${ }^{a}$ Horizon depths are measured from the contact between the top of the paleosol and the overlying sand as shown in figure 7. Horizons $\mathrm{Bt} 1, \mathrm{Bt} 3, \mathrm{Bt} 4$, and $2 \mathrm{C} 2$ were subsampled.

${ }^{b}$ Major-element data from the laboratory are in milligrams per kilogram $(\mathrm{mg} / \mathrm{kg})$. The ratios presented in this table are based on these data, normalized for ease of comparison. Elemental data that are reported in $\mathrm{mg} / \mathrm{kg}$ are available online in the National Cooperative Soil Survey Soil Characterization Database (National Cooperative Soil Survey, undated) by using the user pedon ID SVA059001.

weak, fine and medium subangular blocky; friable; moderately sticky, moderately plastic; diffuse smooth boundary; 10YR 2/1 thin, discontinuous manganese masses throughout horizon but continuous within large areas on prism faces and as linings in a few voids; common, medium and coarse iron masses lining peds and in voids, and in the matrix $(50 \%$ $7.5 Y R$ 6/6, 50\% $5 Y R$ 6/6); thin, discontinuous $7.5 Y R$ 4/3 argillans on ped faces and lining pores $(\sim 50 \%$ of faces and pores); some pores lined by $7.5 Y R$ 6/6 iron coatings; some $2.5 Y 7 / 2$ very fine sand and silt lining prism faces and pores, forming a "grey" (low chroma) lining; few to common 10YR $8 / 1$ very fine sand and silt "coats" on ped faces; many fine and medium dendritic tubular and vesicular pores. Notes: (1) manganese coatings seem to be more dominant in certain parts of the $40 \mathrm{~cm}$ interval but that may be "apparent" and related to the angle between the cliff face and individual prism faces; (2) silt and very fine sand coats on faces diminish or are nonexistent in deeper horizons (possibly related to desiccation and infilling resulting from periglacial processes); (3) clay films follow the normal pedogenic horizonation pattern but possibly could be related to modern processes due to vegetation on sloughed surfaces. Subsampled: 71-91 cm depth, 4a; and 91-111 cm depth, 4b.

\section{Bt2 - 111-141 cm depth}

$7.5 Y R$ 5/4; silty clay loam ( $28 \%$ clay, $50 \%$ silt, $22 \%$ very fine to fine sand); [loam]; weak very coarse prismatic breaking to weak, fine and medium subangular blocky; friable; moderately sticky, moderately plastic; diffuse smooth boundary; $10 Y R$ 7/1 pore linings and infills of very fine sand and silt, which is also present as $\leq 5 \%$ on ped surfaces; occasional gravel-size coarse fragments; $7.5 Y R \quad 4 / 3$ clay films primarily on ped faces and $7.5 Y R$ 5/6 clay films mostly as thin continuous linings in pores and thin discontinuous coatings on ped surfaces; common, fine dendritic tubular and vesicular pores; few ( $1 \%)$, pores lined with $10 Y R$ 2/1 manganese coatings; $7.5 Y R$ 4/6 and 7.5YR 5/6 iron masses; no obvious roots (at this depth the cut face is farther from the slope face). 
Table 6. Clay mineralogy X-ray diffraction data for the High Point paleosol exposed in the High Point shoreline cliff face, Mason Neck, Virginia.

[Location is shown in figure 2; lat $38.6219^{\circ} \mathrm{N}$., long $77.2050^{\circ} \mathrm{W}$. Abbreviations: cm, centimeters; KK, kaolinite; \%, percent; MI, Mica; VR, vermiculite; $\mathrm{n} / \mathrm{a}$ not applicable; MT, montmorillonite; LE, lepidocrocite]

\begin{tabular}{|c|c|c|c|c|c|c|}
\hline \multirow{2}{*}{$\begin{array}{c}\begin{array}{c}\text { Horizon } \\
\text { designation }\end{array} \\
\begin{array}{c}\text { Eg, loess-eolian } \\
\text { sand }\end{array}\end{array}$} & \multirow{2}{*}{$\begin{array}{l}\begin{array}{c}\text { Horizon depth } \\
\text { interval } \\
\text { (cm) }\end{array} \\
0-5\end{array}$} & \multicolumn{4}{|c|}{$\begin{array}{l}\text { Semiquantitative class of clay mineral peak size (area under curve) }(5 \text {, very } \\
\text { large; } 4 \text {, large; } 3 \text {, medium; } 2 \text {, small; } 1 \text {, very small) }\end{array}$} & \multirow{2}{*}{$\begin{array}{r}\text { KK } \\
(\%)\end{array}$} \\
\hline & & $\mathrm{MI} \cdot 3$ & $\mathrm{KK} \cdot 3$ & $\mathrm{VR}^{\mathrm{c}} \cdot 2$ & $\mathrm{n} / \mathrm{a}$ & \\
\hline $\begin{array}{l}\text { Bw1, water-lain } \\
\text { loess }\end{array}$ & $5-38$ & $\mathrm{KK} \cdot 3$ & $\mathrm{MI} \cdot 3$ & $\mathrm{VR} \cdot 3$ & $\mathrm{MT} \cdot 1$ & 40 \\
\hline $\begin{array}{l}\text { Bw2, water-lain } \\
\text { loess }\end{array}$ & $38-71$ & $\mathrm{MI} \cdot 3$ & $\mathrm{KK} \cdot 3$ & $\mathrm{MT} \cdot 2$ & $\mathrm{VR} \cdot 2$ & 24 \\
\hline $\begin{array}{l}\text { Bt1, loess-allu- } \\
\quad \text { vium }\end{array}$ & $71-111$ & $\mathrm{MI} \cdot 3$ & $\mathrm{KK} \cdot 3$ & $\mathrm{VR} \cdot 3$ & MT $\cdot 2$ & 34 \\
\hline $\begin{array}{l}\text { Bt2, loess-allu- } \\
\text { vium }\end{array}$ & 111-141 & $\mathrm{MI} \cdot 3$ & $\mathrm{KK} \cdot 3$ & MT 3 & $\mathrm{VR} \cdot 1$ & 34 \\
\hline Bt3, alluvium & 141-180 & $\mathrm{MI} \cdot 3$ & $\mathrm{MT} \cdot 3$ & $\mathrm{KK} \cdot 3$ & LE 2 & 36 \\
\hline Bt4, alluvium & $180-228$ & $\mathrm{MI} \cdot 3$ & $\mathrm{MT} \cdot 3$ & $\mathrm{KK} \cdot 3$ & $\mathrm{LE} \cdot 1$ & 33 \\
\hline 2Ctg, alluvium & $228-246$ & MT 3 & $\mathrm{MI} \cdot 3$ & $\mathrm{KK} \cdot 3$ & $\mathrm{n} / \mathrm{a}$ & 34 \\
\hline 2C1, alluvium & $246-264$ & $\mathrm{MI} \cdot 3$ & MT 3 & $\mathrm{KK} \cdot 3$ & $\mathrm{LE} \cdot 1$ & 35 \\
\hline $2 \mathrm{C} 2$, alluvium & 264-284 & MT 3 & $\mathrm{MI} \cdot 3$ & $\mathrm{KK} \cdot 3$ & $\mathrm{n} / \mathrm{a}$ & 36 \\
\hline 2C3, alluvium & 284-303 & MT 4 & $\mathrm{MI} \cdot 3$ & $\mathrm{KK} \cdot 3$ & $\mathrm{n} / \mathrm{a}$ & 32 \\
\hline
\end{tabular}

${ }^{a}$ Horizon depths are measured from the contact between the top of the paleosol and the overlying sand as shown in figure 7. Horizons Bt1, Bt3, Bt4, and 2C2 were subsampled.

${ }^{b}$ Kaolinite percent is determined by thermal analysis (endotherm peak area).

${ }^{c}$ Vermiculite (VR) includes hydroxy interlayered vermiculite.

Bt3 - 141-180 cm depth

7.5 YR $5 / 4$; loam (25\% clay, $40 \%$ silt, $35 \%$ very fine to fine sand); [loam]; weak coarse to very coarse prismatic breaking to weak fine and medium subangular blocky; friable; slightly sticky, slightly plastic; gradual smooth boundary; many fine and medium dendritic tubular and vesicular pores; one prism face has gray linings and few fine modern roots; no apparent rock fragments or pebbles. Notes: (1) matrix color is the same as superjacent horizon but there is more of the orange (high chroma) colors as argillans and more grey colors as linings; (2) iron-mass colors are same as superjacent horizon. Subsampled: $141-161 \mathrm{~cm}$ depth, $6 \mathrm{a}$; and $161-180 \mathrm{~cm}$ depth, $6 \mathrm{~b}$.

Bt4 - 180-228 cm depth

$7.5 Y R 5 / 4$; loam ( $20 \%$ clay, $40 \%$ silt, $40 \%$ very fine to fine sand); [loam]; weak coarse to very coarse prismatic breaking to weak, fine and medium subangular blocky structure; friable; slightly sticky, slightly plastic; smooth clear boundary; distinct 7.5YR 4/6-7.5YR 5/6 (7.5YR 4/6 dominant in abundance) iron masses make up $\sim 35 \%$ of matrix and masks the matrix surface color; common, fine, dendritic tubular and vesicular pores that occur in pockets; iron and clay coats ( $7.5 Y R$, few; $7.5 Y R 4 / 6$, dominant) in some pores; manganese coatings more continuous on prism faces and down root channels and similar to those in $\mathrm{Bt} 1$ and $\mathrm{Bt} 2$ horizons, are thin and continuous in a large areas on ped faces, and get "broader" when they encounter large pores and locally thin to nothing; 2 - to 5-cm-thick 2.5 YR 5/4 discontinuous clay "drape" or lens at base of horizon (223-228 cm depth). Notes: (1) horizon has much less porosity, apparently because of decrease in the number of pores and an increase in pore-infilling; (2) there appears to be a mix of sandy pockets and channels in the matrix but the iron is diffuse through the matrix; (3) there are significantly fewer argillans particularly on ped faces; (4) clay lens at base of horizon was sampled for pollen, but no palynomorphs (pollen or spores) were identified. Subsampled: 180-204 cm depth, 7a; and 204-228 cm depth, $7 \mathrm{~b}$. 
Table 7. Selected trace-element data for the High Point paleosol exposed in the High Point shoreline cliff face, Mason Neck, Virginia.

[Location is shown in figure 2; lat $38.6219^{\circ} \mathrm{N}$., long $77.2050^{\circ} \mathrm{W}$. Element symbols: Ba, barium; Be, beryllium; Sr, strontium; P, phosphorus; Se, selenium; $\mathrm{Hg}$, mercury. Abbreviations: cm, centimeters; $\mathrm{mg} / \mathrm{kg}$, milligrams per kilogram; $\mu \mathrm{g} / \mathrm{kg}$, micrograms per kilogram]

\begin{tabular}{|c|c|c|c|c|c|c|c|}
\hline \multirow{2}{*}{$\begin{array}{c}\text { Horizon } \\
\text { Designation }\end{array}$} & \multirow{2}{*}{$\begin{array}{l}\text { Horizon depth } \\
\text { interval } \\
(\mathbf{c m})^{\mathrm{a}}\end{array}$} & \multicolumn{6}{|c|}{ Selected trace-element datab } \\
\hline & & $\begin{array}{c}\mathrm{Ba} \\
(\mathrm{mg} / \mathrm{kg})\end{array}$ & $\begin{array}{c}\mathrm{Be} \\
(\mathrm{mg} / \mathrm{kg})\end{array}$ & $\begin{array}{c}\mathrm{Sr} \\
(\mathrm{mg} / \mathrm{kg})\end{array}$ & $\begin{array}{c}P \\
(\mathrm{mg} / \mathrm{kg})\end{array}$ & $\begin{array}{c}\mathrm{Se} \\
(\mu \mathrm{g} / \mathrm{kg})\end{array}$ & $\begin{array}{c}\mathrm{Hg} \\
(\mu \mathrm{g} / \mathrm{kg})\end{array}$ \\
\hline $\begin{array}{l}\text { Eg, } \\
\text { loess-eolian } \\
\text { sand }\end{array}$ & $0-5$ & 247.8 & 1.3 & 45.5 & 26.4 & 197.2 & 193 \\
\hline $\begin{array}{l}\text { Bw1, } \\
\quad \text { water-lain loess }\end{array}$ & $5-38$ & 283.2 & 1.8 & 45.6 & 45.2 & 577.6 & 191 \\
\hline $\begin{array}{l}\text { Bw2, } \\
\text { water-lain loess }\end{array}$ & $38-71$ & 342.3 & 2.2 & 59.0 & 54.7 & 546.8 & 191 \\
\hline $\begin{array}{l}\text { Bt1, } \\
\text { loess-alluvium }\end{array}$ & $71-91$ & 236.3 & 1.9 & 46.7 & 57.7 & 435.6 & 195 \\
\hline $\begin{array}{l}\text { Bt1, } \\
\text { loess-alluvium }\end{array}$ & $91-111$ & 190.3 & 1.6 & 36.9 & 39.8 & 539.0 & 0 \\
\hline $\begin{array}{l}\text { Bt2, } \\
\quad \text { loess-alluvium }\end{array}$ & $111-141$ & 276.4 & 2.1 & 53.4 & 68.6 & 373.8 & 0 \\
\hline $\begin{array}{l}\text { Bt3, } \\
\text { alluvium }\end{array}$ & $141-161$ & 248.1 & 1.8 & 50.5 & 56.0 & 302.4 & 0 \\
\hline $\begin{array}{l}\text { Bt3, } \\
\quad \text { alluvium }\end{array}$ & $161-180$ & 103.5 & 1.2 & 19.5 & 34.5 & 204.4 & 3 \\
\hline $\begin{array}{l}\text { Bt4, } \\
\quad \text { alluvium }\end{array}$ & 180-204 & 80.5 & 0.8 & 14.7 & 14.8 & 131.3 & 0 \\
\hline $\begin{array}{l}\text { Bt4, } \\
\quad \text { alluvium }\end{array}$ & 204-228 & 86.7 & 0.8 & 17.8 & 22.5 & 232.6 & 0 \\
\hline $\begin{array}{l}2 \mathrm{Ctg}, \\
\text { alluvium }\end{array}$ & $228-246$ & 83.0 & 1.0 & 16.0 & 35.9 & 182.3 & 4 \\
\hline $\begin{array}{l}2 \mathrm{C} 1, \\
\quad \text { alluvium }\end{array}$ & $246-264$ & 62.7 & 0.7 & 13.3 & 14.9 & 137.7 & 1 \\
\hline $\begin{array}{l}2 \mathrm{C} 2 \\
\quad \text { alluvium }\end{array}$ & $264-284$ & 41.1 & 0.3 & 8.6 & 0.0 & 61.8 & 0 \\
\hline $\begin{array}{l}2 \mathrm{C} 3 \\
\quad \text { alluvium }\end{array}$ & $284-303$ & 51.9 & 0.6 & 9.9 & 23.3 & 184.0 & 0 \\
\hline
\end{tabular}

${ }^{a}$ Horizon depths are measured from the contact between the top of the paleosol and the overlying sand as shown in figure 7. Horizons Bt1, Bt3, Bt4, and 2C2 were subsampled.

${ }^{b}$ Complete trace-element data for this site from the Kellogg Soil Survey Lab can be accessed online in the National Cooperative Soil Survey Soil Characterization Database (National Cooperative Soil Survey, undated) by using the user pedon ID SVA059001. 
$2 \mathrm{Ctg}-228-246 \mathrm{~cm}$ depth

$7.5 Y R$ 5/3; loamy fine sand; [fine sandy loam]; massive; firm; non sticky, non-plastic; smooth clear boundary; few fine and medium pores with an occasional pore lined by argillans or manganese coatings; common fine and medium $7.5 Y R$ 5/6 iron masses throughout; areas of horizon cemented by iron; iron staining and cementing and depletions extend from the overlying horizon; some tubular pore linings and depletions near the upper boundary with features that are characteristic of the overlying Bt4 horizon. Notes: the cementation of this horizon causes a brittleness when broken between fingers.

\section{$2 \mathrm{C} 1-246-264 \mathrm{~cm}$ depth}

Mixed 10YR 7/1, 10YR 7/2, and 2.5Y 6/3 (dominant colors); loam to loamy sand (texture mixture is both across the thickness and width of horizon in outcrop); [fine sandy loam]; massive where cemented, which is most of it, but single grain where uncemented; very firm to friable depending on cementation; manganese and iron colors same as in horizon $2 \mathrm{Ctg}$ horizon; occasional medium pore; non apparent argillans; manganese lines cracks and pressure faces(?) in upper part of horizon; iron stains aligned with sedimentary structures in the very fine and fine sand and the loamy fine sand.

\section{$2 \mathrm{C} 2-264-303 \mathrm{~cm}$ depth}

$2.5 Y 6 / 2$ but is also mixed in places with same colors as in $2 \mathrm{C} 1$ horizon; fine sand; [loamy fine sand and fine sandy loam]; massive where cemented, which is most of it, but single grain where uncemented; manganese is $<2 \%$ in and along moisture/wetting front (limit of rainfall infiltration); some of the iron concentrations occur along the same moisture/ wetting front; iron is also along bedding planes and (or) changes in porosity zones of the sand; iron colors same as in overlying horizons; sand is on the "small end" of fine sand and is predominantly subangular to angular quartz with $3 \%$ or less heavy minerals and feldspar; thickest silt lens was from 298 to $301 \mathrm{~cm}$ near base of horizon. Subsampled: $264-284 \mathrm{~cm}$ depth, $10 \mathrm{a}$; and $284-303 \mathrm{~cm}$ depth, $10 \mathrm{~b}$.

\section{Summary of Pedostratigraphic and Age Data}

The Mason Neck stratigraphy is an aggrading late Pleistocene sedimentary sequence that from oldest to youngest is composed of estuarine sand, silt, and clay (Unit A); estuarine-alluvial sand and silt (Unit B); estuarine-alluvial and water-lain eolian sand and silt (Unit $\mathrm{C}$ and either side of contact with Unit D); and alluvial sand (Unit D). Pollen assemblage data for Unit A (fig. $4 A$ ) indicate a middle to late MIS5 climate slightly cooler than present near sea level in the Potomac River valley (fig. $4 A$ in this report). The prominent paleosol developed in Unit $\mathrm{C}$ represents a time between 86 and $56 \mathrm{ka}$, based on ages for Units B and D, respectively, at the High Point locality. These ages indicate deposition and subsequent emergence of the water-lain sand and silt as well as development of the High Point paleosol occurred in about 30,000 years in late MIS5 and MIS4. Age data for the same units exposed at the Visitor Center and Sycamore Point localities indicate a much shorter time interval of 10,000 to 20,000 years for these processes to occur. Sediment emergence is considered contemporaneous with sea level lowering resulting from climate change and (or) climate-induced crustal deformation (see previous references). The following paragraphs present a preliminary summary of Unit $\mathrm{C}$ sediment, including the High Point paleosol, of the sedimentary sequence exposed in the cliff faces of Mason Neck, and of the processes that dominated landscape modification in the Potomac River valley in the early late Pleistocene, predominantly in MIS4.

- The High Point paleosol is a 2.28-m-thick aggrading soil that developed in a late Pleistocene fining upward sequence of estuarine-alluvial sand to loess that is younger than $86 \mathrm{ka}$. The $\mathrm{E}, \mathrm{Bw}, \mathrm{Bt}$, and $\mathrm{C}$ horizon sequence of the paleosol indicates subaerial pedogenesis during and after estuarine-alluvial sand and silt deposition. Pedogenesis started with initial estuarine/ floodplain emergence as sea level was lowering in late MIS5 and MIS4, continued during and after eolian silt incorporation into the estuarine-alluvial sand and the formation of the 70- to 90-cm-thick loess and eolian sand cap. To the authors' knowledge, this loess-eolian sand cap is the first reported definitive evidence of MIS4 loess deposition in the northern Chesapeake Bay area.

- The High Point paleosol below the Eg horizon is relatively uniformly oxidized (7.5YR 4/4-5/4 matrix color; fig. $7 A$ ). The $\mathrm{Bw}$ horizons are massive water-lain loess. The Bt horizons are bioturbated; characterized by weak, very coarse prismatic, breaking to weak, fine and medium subangular, blocky structure and have significant clay film development. The chemistry and colors of the $\mathrm{Bt}$ horizons indicate development during a period of warm, humid climate.

- Particle-size data show a fining upward trend in the alluvium from 228 to $141 \mathrm{~cm}$ (Bt4 and Bt3 horizons). From 141 to $71 \mathrm{~cm}$ (Bt2 and Bt1 horizons), the fining upward trend continues as the alluvium becomes siltier, indicating a transition from alluvium to a waterlain loess-alluvium mix (tables 2, 3). Particle-size data also indicate that the parent material from 71 to $5 \mathrm{~cm}$ (Bw1 and Bw2 horizons) is loess. The very fine sand to fine sand ratios indicate a fining upward deposit with distinct zones/horizons in the paleosol (table 3). The texture of the paleosol in the estuarine-alluvial sand and the estuarine-alluvial sand-loess mix is silty clay 
loam to loam. Texture of the loess $(71-5 \mathrm{~cm})$ is silty clay loam. The Eg-horizon is a mixture of eolian silt and sand and has a silt loam to loam texture. The water content (table 4) and major-element data (table 5), particularly the $\mathrm{Si} / \mathrm{Al}, \mathrm{Si} / \mathrm{Ti}$, and $\mathrm{Mg} / \mathrm{Ca}$ ratios, mirror the particle size break at $141 \mathrm{~cm}$ depth, above which total silt sharply increases.

- Clay-mineral and trace-element data (tables 6 and 7, respectively) indicate that the aggrading High Point paleosol had differing depositional sources and was affected by differing weathering processes as its parent material accumulated. The upper meter of the paleosol is dominated by kaolinite and mica. Montmorillonite is significant in the lower meter of the paleosol. Traceelement concentrations are higher in the upper 1.5 meters of the paleosol. This increase in trace-element concentration in the High Point paleosol possibly is the result of increased weathering but also could be the due to increased tidal or sea-spray components, changes in source area of the eolian silt and sand, or a combination of these possibilities. The relatively high mercury $(\mathrm{Hg})$ values in the upper meter of the paleosol may also indicate a period of abrupt climate change. Mercury concentrations in ice cores have been shown to be higher during global cold periods (Jitaru and others, 2009; fig. 1 and references therein). Unique features (see following paragraph) in the Eg horizon of the High Point paleosol may indicate an abrupt change from a warm humid climate to a much colder climate with seasonal-to-intermittent periglacial activity.

- The Eg paleosol horizon is eolian sand and silt overlain by eolian(?) sand in the basal part of Unit D. Near the Unit D sand/Unit C (paleosol Eg horizon) contact, features indicating freeze-thaw processes are present (fig. 4A). Desiccation cracks (dikes or frost fissures), and bowl-like structures that are characteristic of periglacial processes characterize the upper part of the Eg horizon and the overlying Unit D sand (fig. $7 B$ ). The origin of the gravel is undetermined, but the gravel is similar to that outcropping as the surface unit in the central part of Mason Neck (white circle in fig. 2).

- The gravel lag, bowl-shaped pods, and desiccation cracks (dikes, frost fissures) and the abrupt contact between the paleosol and the overlying sand suggest a period of nondeposition and (or) erosion as well as seasonal-to-intermittent periglacial activity after paleosol development but prior to $56 \mathrm{ka}$.

\section{General Observation Based on Data Presented in this Report}

The late Pleistocene sedimentary sequence exposed in at Mason Neck has characteristics indicating abrupt shifts in the area's climate. Each of these climatic shifts resulted in significant changes to the area's landscape due to changes in geomorphic processes. Changes also included millennial to submillenial vegetation shifts and seasonal to longer-term periods of periglacial activity. The Mason Neck sedimentary sequence and the High Point paleosol record a 10,000- to 30,000-year period of deposition and subsequent emergence of estuarine to eolian sediments in the Potomac River valley downstream from Washington, D.C. Emergence resulted in the present position of late MIS5 to MIS4 estuarine-alluvial sediments at elevations up to $8 \mathrm{~m}$ above present sea level. Optically stimulated luminescence ages indicate that the Mason Neck sedimentary sequence provides a record of sediment deposition and emergence as well as changes in geomorphic processes that occurred between 86 and $56 \mathrm{ka}$. In their studies of spatial/temporal relations of late Pleistocene sediments in the northern Chesapeake Bay area, Pavich and others (2009) and DeJong and others (2015) noted the importance of understanding the spatial, temporal, and geomorphic processes affecting the northern Chesapeake Bay area in order to develop predictive models for future climate and sea level change. Additional research could further improve our understanding of the drivers for these processes and forecast their short- and long-term results. Studies such as this one on Mason Neck provide the opportunity to bracket the time intervals during which processes such as deposition, submergence, emergence, soil formation, and climate shifts occur. More detailed investigations can provide data for modeling future climate and sea-level change in the area.

\section{References Cited}

Berman, M., 2010, How long is Virginia's shoreline?: Virginia Institute of Marine Science web page, accessed July 7, 2021, at https://www.vims.edu/bayinfo/faqs/ shoreline_miles.php.

Burt, R., and Natural Resources Conservation Service Soil Survey Staff, comps., 2014, Kellogg Soil Survey Laboratory methods manual (ver. 5.0): Natural Resources Conservation Service, Soil Survey Investigations Report No. 42, 1,031 p., accessed December 6, 2021, at https://www.nrcs.usda.gov/wps/portal/nrcs/detail/soils/ research/guide/?cid=nrcs142p2_054247. 
Davis, A.M., Southworth, C.S., Reddy, J.E., and Schindler, J.S., 2001, Geologic map database of the Washington DC area featuring data from three $30 \times 60$ minute quadrangles; Frederick, Washington West, Fredericksburg: U.S. Geological Survey Open-File Report OF-2001-227, 2 sheets, scale 1:100,000, accessed January 25, 2021, at https://ngmdb.usgs.gov/Prodesc/proddesc_51791.htm.

DeJong, B.J., Bierman, R.R., Newell, W.L., Rittenour, T.M., Mahan, S.A., Balco, G., and Rood, D.H., 2015, Pleistocene relative sea levels in the Chesapeake Bay region and their implications for the next century: GSA Today, v. 25 , no. 8 , p. $4-10$, accessed January 31 , 2021, at https://doi.org/10.1130/GSATG223A.1.

Divins, D.L., and Metzer, D., [undated], National Geophysical Data Center coastal relief model: National Oceanic and Atmospheric Administration web page, accessed May 2006, at https://www.ngdc.noaa.gov/mgg/coastal/coastal.html.

Eulie, D.O., Walsh, J.P., Corbett, D.R., and Mulligan, R.P., 2017, Temporal and spatial dynamics of estuarine shoreline change in the Albemarle-Pamlico Estuarine System, North Carolina, USA: Estuaries and Coasts, v. 40, no. 3, p. 741-757, accessed June 3, 2021, at https://doi.org/10.1007/s12237-016-0143-8.

Feldman, S.B., Zelazny, L.W., Pavich, M.J., and Millard, H.T., 2000, Late Pleistocene aeolian activity and post depositional alteration on the Piedmont of northern Virginia: Southeastern Geology, v. 39, no. 3-4, p. 183-198, accessed January 26, 2021, at http://libres.uncg.edu/ir/asu/f/ SoutheasternGeology_Vol39_No3\&4_2000.pdf.

French, H.M., Demitroff, M., Forman, S.L., and Newell, W.L., 2007, A chronology of late-Pleistocene permafrost events in southern New Jersey, eastern USA: Permafrost and Periglacial Processes, v. 18, no. 1, p. 49-59, accessed April 2, 2021, at https://doi.org/10.1002/ppp.572.

French, H.M., Demitroff, M., and Newell, W.L., 2009, Past permafrost on the Mid-Atlantic Coastal Plain, eastern United States: Permafrost and Periglacial Processes, v. 20, no. 3, p. 285-294, accessed April 2, 2021, at https://doi.org/10.1002/ppp.659.

Jitaru, P., Gabrielli, P., Marteel, A., Plane, J.M.C., Planchon, F.A.M., Gauchard, P.-A., Ferrari, C.P., Boutron, C.F., Adams, F.C., Hong, S., Cescon, P., and Barbante, C., 2009, Atmospheric depletion of mercury over Antarctica during glacial periods: Nature Geoscience, v. 2, no. 7, p. 505-508, accessed June 22, 2021, at https://doi.org/10.1038/ngeo549.
Litwin, R.J., Smoot, J.P., Pavich, M.J., Markewich, H.W., Brook, G.A., and Durika, N.J., 2013, 100,000-yearlong terrestrial record of millennial-scale linkage between eastern North American mid-latitude paleovegetation shifts and Greenland ice-core oxygen isotope trends: Quaternary Research, v. 80, no. 2, p. 291-315, accessed January 30, 2021, at https://doi.org/10.1016/j. yqres.2013.05.003.

Litwin, R.J., Smoot, J.P., Pavich, M.J., Markewich, H.W., Brook, G.A., and Verardo, S., 2010, Hybla cores 7 \& 8-An 80,000 -year late Pleistocene climate record from the midAtlantic Coastal Plain of North America [abs.]: Geological Society of America Abstracts with Programs, v. 42, no. 1, p. 151, accessed April 26, 2021, at https://gsa.confex.com/ gsa/2010NE/webprogram/Paper168994.html.

Lowery, D.L., O’Neal, M.A., Wah, J.S., Wagner, D.P., and Stanford, D.J., 2010, Late Pleistocene upland stratigraphy of the western Delmarva Peninsula, USA: Quaternary Science Reviews, v. 29, no. 11-12, p. 1472-1480, accessed January 30, 2021, at https://doi.org/10.1016/j.quascirev.2010.03.007.

Lyttle, P.T., Aleinikoff, J.N., Burton, W.C., Crider, E.A., Jr., Drake, A.A., Jr., Froelich, A.J., Horton, J.W., Jr., Kasselas, G., Mixon, R.B., McCartan, L., Nelson, A.E., Newell, W.L., Pavlides, L., Powars, D.S., Southworth, C.S., and Weems, R.E., 2017, Geologic map of the Washington West $30^{\prime} \times 60^{\prime}$ quadrangle, Maryland, Virginia, and Washington D.C.: 1 sheet, scale 1:100,000, accessed January 25, 2021, at https://pubs.usgs.gov/of/2017/1142/ ofr20171142.pdf.

Mallinson, D., Burdette, K., Mahan, S., and Brook, G., 2008, Optically stimulated luminescence age controls on late Pleistocene and Holocene coastal lithosomes, North Carolina, USA: Quaternary Research, v. 69, no. 1, p. 97-109, accessed April 5, 2021, at https://doi.org/10.1016/j.yqres.2007.10.002.

Markewich, H.W., Litwin, R.J., Pavich, M.J., and Brook, G.A., 2009, Late Pleistocene eolian features in southeastern Maryland and Chesapeake Bay region indicate strong WNW-NW winds accompanied growth of the Laurentide Ice Sheet: Quaternary Research, v. 71, no. 3, p. 409-425, accessed February 16, 2021, at https://doi.org/10.1016/j.yqres.2009.02.001.

Markewich, H.W., Litwin, R.J., Wysocki, D.A., and Pavich, M.J., 2015, Synthesis on Quaternary aeolian research in the unglaciated eastern United States: Aeolian Research, v. 17, p. 139-191, accessed November 12, 2020, at https://doi.org/10.1016/j.aeolia.2015.01.011. 
Mixon, R.B., Berquist, C.R., Jr., Newell, W.L., Johnson, G.H., Powars, D.S., Schindler, J.S., and Rader, E.K., 1989, Geological map and generalized cross sections of the Coastal Plain and adjacent parts of the Piedmont, Virginia: U.S. Geological Survey Miscellaneous Investigations Series Map I-2033, 2 sheets, scale 1:250,000, accessed January 25, 2021, at https://ngmdb.usgs.gov/Prodesc/ proddesc_10097.htm.

Mixon, R.B., Szabo, B.J., and Owens, J.P., 1982, Uraniumseries dating of mollusks and corals, and age of Pleistocene deposits, Chesapeake Bay area, Virginia and Maryland: U.S. Geological Survey Professional Paper 1067-E, 18-p. pamphlet, 2 pls., accessed January 25, 2021, at https://doi.org/10.3133/pp1067E.

Muhs, D.R., 2021, Soils and paleosols, in Alberton, D., and Elias, S.D., eds., Encyclopedia of Geology (2d ed.): v. 5, p. 370-384, accessed April 29, 2021, at https://doi.org/10.1016/B978-0-12-409548-9.12002-0.

National Cooperative Soil Survey, [undated], National Cooperative Soil Survey (NCSS) soil characterization database: NCSS database, accessed November 30, 2021, at https://ncsslabdatamart.sc.egov.usda.gov/. [NCSS soil characterization basic query; user pedon ID SVA059001.]

Newell, W.L., and Clark, I., 2008, Geomorphic map of Worcester County, Maryland, interpreted from a LiDARbased, digital elevation model: U.S. Geological Survey Open-File Report 2008-1005, 34-p. pamphlet, 2 pls., accessed April 17, 2021, at https://pubs.usgs.gov/ of/2008/1005/.

Newell, W.L., and DeJong, B.D., 2011, Cold-climate slope deposits and landscape modifications of the Mid-Atlantic Coastal Plain, Eastern USA: Geological Society Special Publication, London, United Kingdom, p. 259-276, accessed April 2, 2021, at https://doi.org/10.1144/SP354.17.

Oaks, R.Q., Jr., and Coch, N.K., 1973, Post-Miocene stratigraphy and morphology, southeastern Virginia: Virginia Division of Mineral Resources Bulletin 82, 135 p., 2 sheets, accessed January 26, 2021, at https:/www.dmme.virginia. gov/commerce/ProductDetails.aspx? productID $=2507$.

Pavich, M.J., Markewich, H.W., Litwin, R.J., and Smoot, J., 2009, Sea level history of Chesapeake Bay since $117 \mathrm{ka}$ based on OSL dating of estuarine sediments [abs.]: Geological Society of America Abstracts with Programs, v. 41, no. 7, p. 351, accessed January 25, 2021, at https:/gsa.confex.com/gsa/2009AM/webprogram/ Paper163344.html.
Pavich, M.J., Markewich, H.W., Wysocki, D.A., Litwin, R.J., Smoot, J.P., and Brook, G., 2010, High Point paleosolRecord of early Wisconsinan pedogenesis on the Potomac River [abs.]: Geological Society of America Abstracts with Program, v. 42, no. 5, p. 231, accessed January 26, 2021, at https://gsa.confex.com/gsa/2010AM/webprogram/ Paper178686.html.

Potter, E.-K., and Lambeck, K., 2004, Reconciliation of sealevel observations in the western North Atlantic during the last glacial cycle: Earth and Planetary Science Letters, v. 217, no. 1-2, p. 171-181, accessed May 26, 2021, at https://doi.org/10.1016/S0012-821X(03)00587-9.

Railsback, L.B., Gibbard, P.L., Head, M.J., Voarintsoa, N.R.G., and Toucanne, S., 2015, An optimized scheme of lettered marine isotope substages for the last 1.0 million years, and the climatostratigraphic nature of isotope stages and substages: Quaternary Science Reviews, v. 111, p. 94-106, accessed November 12, 2020, at https://doi.org/10.1016/j. quascirev.2015.01.012.

Schoeneberger, P.J., Wysocki, D.A., Benham, E.C., and Broderson, W.D., 2003, Field book for describing and sampling soils [ver. 2.0]: Natural Resources Conservation Service, U.S. Department of Agriculture (USDA), National Soil Survey Center, Lincoln, Neb., 228 p.

Scott, T.W., Swift, D.J.P., Whittecar, G.R., and Brook, G.A., 2010, Glacioisostatic influences on Virginia's late Pleistocene coastal plain deposits: Geomorphology, v. 116, no. 1-2, p. 175-188, accessed April 27, 2021, at https://doi.org/10.1016/j.geomorph.2009.10.017.

Soil Science Division Staff, 2017, Soil survey manual (4th ed.): U.S. Department of Agriculture (USDA) Handbook 18, 640 p., accessed November 16, 2021, at https://nrcspad.sc.egov.usda.gov/DistributionCenter/ pdf.aspx?productID $=1363$.

Stanford, S.D., Stone, B.D., Ridge, J.C., Witte, R.W., Pardi, R.R., and Reimer, G.E., 2021, Chronology of Laurentide glaciation in New Jersey and New York City area, United States: Quaternary Research, v. 99, p. 142-167, accessed March 11, 2021, at https://doi.org/10.1017/ qua.2020.71.

Valentine, K.W.G., and Dalrymple, J.B., 1976, Quaternary buried paleosols - A critical review: Quaternary Research, v. 6, no. 2, p. 209-222, accessed January 27, 2021, at https://doi.org/10.1016/0033-5894(76)90051-X. 
Wah, J.S., Wagner, D.P., and Lowery, D.L., 2018, Loess in the mid-Atlantic region, USA: Quaternary Research, v. 89 , no. 3, p. 786-796, accessed January 27,2021 , at https://doi.org/10.1017/qua.2017.113.

Wehmiller, J.F., Simmons, K.R., Cheng, H., Edwards, R.L., Martin-McNaughton, J., York, L.L., Krantz, D.E., and Shen, C.-C., 2004, Uranium series coral ages from the US Atlantic Coastal Plain-The "80 ka problem" revisited: Quaternary International, v. 120, no. 1, p. 3-14, accessed January 25, 2021, at https://doi.org/10.1016/j.quaint.2004.01.002.
Wysocki, D.A., Markewich, H.W., Pavich, M.J., Litwin, R.J., and Smoot, J.P., 2010, Looking for loess in all the wrong places - Characteristics and geomorphic inferences of a late-Pleistocene (OIS 5a and 4) paleosol in silt-rich coastal plain deposits along the Potomac River in southeastern Virginia [abs.]: American Society of Agronomy, Crop Science Society of America, and Soil Science Society of America, 2010 International Annual Meetings, Oct. 31-Nov. 4, 2010, Long Beach, Calif., accessed January 25, 2021, at http://a-c-s.confex.com/crops/2010am/ webprogram/Paper60303.html. 



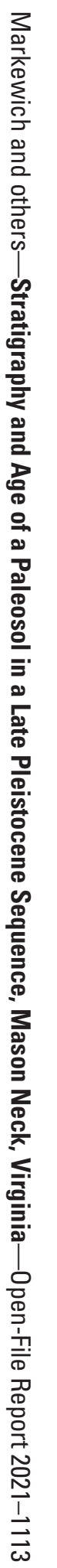

